
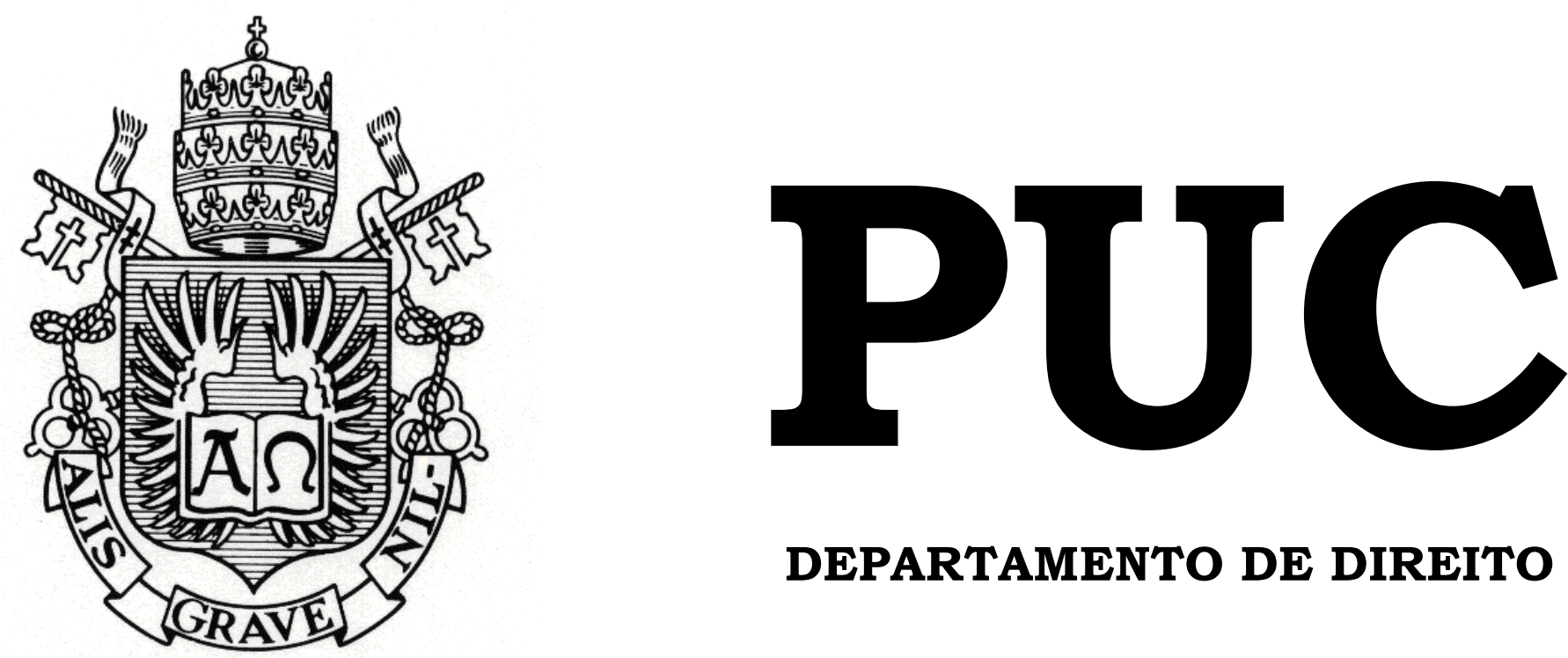

DEPARTAMENTO DE DIREITO

Admirável Uber Novo:

Um Estudo sobre a Relação de Trabalho entre Trabalhadores Motoristas e Empresas de Transporte de Pessoas por Intermédio de Aplicativos

por

THAÍS CORTEZ RIBEIRO DA SILVA

ORIENTADOR: JOÃO BATISTA BERTHIER LEITE SOARES 2019.2

PONTIFÍCIA UNIVERSIDADE CATÓLICA DO RIO DE JANEIRO RUA MARQUÊS DE SÃO VICENTE, 225 - CEP 22453-900 RIO DE JANEIRO - BRASIL 


\title{
Admirável Uber Novo: \\ Um Estudo sobre a Relação de Trabalho entre Trabalhadores Motoristas e Empresas de Transporte de Pessoas por Intermédio de Aplicativos
}

\author{
por
}

\section{THAÍS CORTEZ RIBEIRO DA SILVA}

Monografia

apresentada

ao

Departamento de Direito da Pontifícia Universidade Católica do Rio de Janeiro (PUC-Rio) para a obtenção do Título de Bacharel em Direito.

Orientador: João Batista Berthier Leite Soares 
Dedico este trabalho aos meus pais, Rosemere $e$ Athaide, como meus esforços e sucessos sempre serão. 


\section{AGRADECIMENTOS}

Agradeço, em primeiro lugar, e sempre, aos meus pais. Não me soa inverídica a premissa de que filhos sejam criados para o mundo. Filhos, como eu, crescem, ganham consciência e sonhos próprios, que os fazem escrever suas próprias histórias. Ocorre que nesse processo, nós, filhos, nem sempre temos a oportunidade - ou quando temos não a aproveitamos -, de agradecer pelas oportunidades que nos dão. Por isso, aos meus pais, Rosemere e Athaide, agradeço por sempre me ampararem com uma educação nas melhores estruturas acadêmicas e familiares possíveis, e me darem asas para voar em direções que, por vezes, até eu duvido possíveis - embora eles jamais.

Agradeço, também, à minha família, por demonstrar compreensão e apoio às minhas presentes ausências e alterações de humor em meio ao último ano de faculdade.

Agradeço ao meu orientador, Professor João Batista Berthier Leite Soares, por despertar meu interesse pelo Direito do Trabalho, tamanha sua devoção pela disciplina.

Agradeço ao Curso de Direito da PUC-Rio, por me proporcionar experiências profissionais, acadêmicas e pessoais transformadoras.

Por fim, mas sem dúvidas, não menos importante, agradeço aos meus bons amigos, aqui representados por Pedro Jorge e Mariana Rodrigues, por trazerem leveza aos meus dias. 


\section{RESUMO}

Novas bases técnicas no capitalismo emergiram com a tecnologia e deram azo à novas formas de trabalho através da economia de compartilhamento. Propõe-se a observar a potencial precariedade do novo trabalho, a partir do fenômeno da Uberização, e qual a regulação jurídica cabível a tal labor, focalizando o caso dos motoristas vinculados à empresa Uber. Trata-se de uma empresa modelo do que se vende como a prática de compartilhamento, de grande potencial de replicação do seu modelo de negócios e, como se constatou, também de precarização do trabalho. Notouse que o trabalho "uberizado" ainda carece de uma proteção jurídica sólida. As técnicas de pesquisa adotadas para coleta e análise de dados foram a revisão bibliográfica, com o uso da metodologia dialética, contrapondo as ideias dos autores de maior renome na seara trabalhista; o estudo da legislação pertinente; e a análise jurisprudencial, selecionadas decisões paradigmáticas, internacionais e nacionais, a partir de 2015.

Palavras-chave: vínculo empregatício; trabalho autônomo; Uberização; Uber; motorista. 


\section{SUMÁRIO}

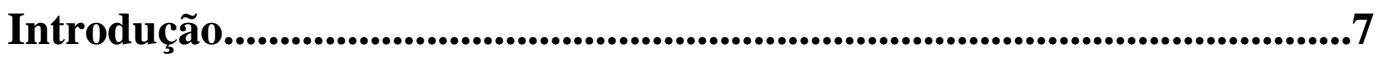

\section{Capítulo 1 - Os Elementos Fático-Jurídicos Caracterizadores da} Relação de Emprego..................................................................................................10

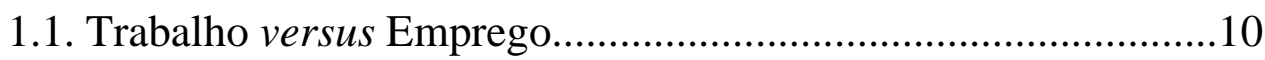

2.2. Trabalho prestado por pessoa física...............................................11

2.3. Trabalho prestado com pessoalidade............................................12

2.4. Trabalho prestado com não eventualidade, ineventualidade ou habitualidade ................................................................................14

2.5. Trabalho prestado com onerosidade..............................................16

2.6. Trabalho prestado com subordinação jurídica...............................18

2.6.1. A natureza da subordinação............................................20

2.6.2. Dimensões da subordinação...........................................22

Capítulo 2 - Características e Reflexos do Fenômeno da "Uberização" nas Relações de Trabalho.......................................................................................24

2.1. A nova base técnica do capitalismo no meio ambiente digital e o

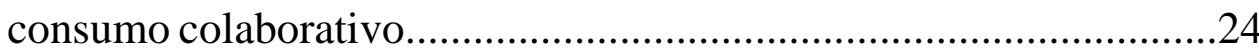

2.2. A Uber como expoente do consumo colaborativo: como funciona

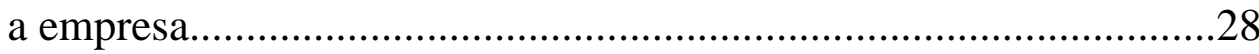

2.3. O fenômeno da "Uberização"..........................................................31

Capítulo 3 - Aspectos Jurídicos do Trabalho do Motorista da Uber.....36

3.1. Casos paradigmáticos da Uber nos Tribunais Internacionais.......36

3.2. Casos paradigmáticos da Uber nos Tribunais Brasileiros............44 


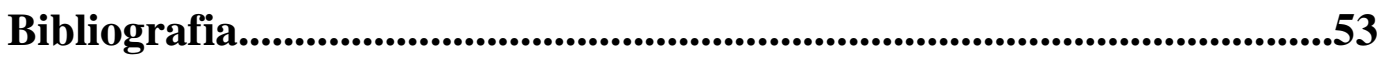




\section{LISTA DE ABREVIATURAS}

Art. - Artigo

CADE - Conselho Administrativo de Defesa Econômica

CLT - Consolidação das Leis do Trabalho

CRFB/88 - Constituição da República Federativa do Brasil

CTPS - Carteira de Trabalho e Previdência Social

LC - Lei Complementar

MPT - Ministério Público do Trabalho

$\mathrm{N}^{\mathrm{o}}-$ Número

RO - Recurso Ordinário

STF - Supremo Tribunal Federal

TJUE - Tribunal de Justiça da União Europeia

TRT - Tribunal Regional do Trabalho

TST - Tribunal Superior do Trabalho 


\section{INTRODUÇÃO}

As ramificações do Direito surgem com o fim de tutelar as necessidades peculiares de relações jurídicas específicas. O Direito do Trabalho apresenta o propósito de aprimorar as condições de pactuação da força de trabalho ${ }^{1}$ e de promover a melhor condição social do trabalhador ${ }^{2}$. Habitualmente, sua tutela recai sobre a relação de emprego, pois a realidade fática sobre a qual incide é a do trabalho livre, subordinado e contínuo, fruto da própria sociedade industrial urbana. Como leciona Maurício Godinho Delgado, "a pesquisa sobre a caracterização da relação de emprego é essencialmente uma pesquisa em torno da modernidade $(. . .)^{\prime \prime 3}$.

Dessa forma, para que o Direito Trabalhista cumpra o seu papel, é primordial que os sujeitos da relação de trabalho sejam identificados. Tratase de uma tarefa controversa, em sede jurisprudencial e doutrinária ${ }^{4}$, que se torna ainda mais árdua, apesar de não menos elementar, nos tempos atuais em que a tecnologia confere novas formas ao trabalho.

Nesse mundo pós-industrial, a perfeita ilustração da forma de trabalho emergente 5 é o "motorista Uber". Trabalhador motorista não profissional, que se inscreve, por vontade própria, em uma plataforma virtual cujo papel, alegadamente, seria o de mediar a oferta e demanda entre motoristas e usuários. O trabalhador utiliza o seu próprio veículo para o labor e usa o seu próprio dinheiro para as despesas relacionadas ao veículo. No entanto, é

\footnotetext{
${ }^{1}$ DELGADO, Mauricio Godinho. Curso de Direito do Trabalho. $16^{\mathrm{a}}$ ed. São Paulo: LTr, 2017. p. 54.

${ }^{2}$ NASCIMENTO, Amauri Mascaro. Curso de Direito do Trabalho. $24^{\text {a }}$ ed. São Paulo, Saraiva, 2009. p. 8.

${ }^{3}$ DELGADO, Maurício Godinho. Op. Cit., p. 313.

${ }^{4}$ Ibid. p. 611.

${ }^{5}$ Nelson Mannrich atenta para a diferença entre "novas formas de trabalho" e "novas modalidades de contratação". Estas, enquanto formas de contrato atípicas que fogem ao padrão clássico de proteção; ao passo que aquelas, como alternativas ao trabalho subordinado típico. MANNRICH, Nelson. Empregabilidade, ocupação e novas formas de trabalho. Revista da Faculdade de Direito da Universidade de São Paulo. São Paulo, v. 100, p. 103-119, jan. /dez. 2005. (Disponível em <https://www.revistas.usp.br/rfdusp/article/download/67666/70274/>. Acesso em 31.out.18.)
} 
obrigado a destinar um percentual de $25 \%$ do valor total de cada corrida feita à empresa, bem como seguir "regras de conduta" (sob risco de punição), além de ser constantemente avaliado pelos usuários. Para a empresa: trabalhador autônomo. Para o Judiciário: controvérsia.

Nota-se que, se por um lado, as dinâmicas das relações de trabalho superaram a dicotomia subordinação versus autonomia; por outro, a legislação laboral que as regula não foi capaz de se modificar na mesma velocidade. A incerteza quanto à natureza do vínculo empregatício entre motoristas e empresas de aplicativos eletrônicos, com decisões judiciais que ora reconhecem o liame empregatício, ora o negam, gera insegurança aos trabalhadores e às empresas. Dessa forma, este estudo busca, pelas técnicas de pesquisa à doutrina, à legislação e à jurisprudência, apontar normas aplicáveis à referida controvérsia e aclarar os posicionamentos judiciais até então proferidos.

O trabalho foi dividido em três capítulos. No primeiro, são apresentados os elementos caracterizadores da relação empregatícia, com amparo na doutrina majoritária e na legislação pertinente. Distingue-se a relação de trabalho da relação de emprego e são analisados os pressupostos da prestação de trabalho por pessoa física, da pessoalidade, da habitualidade, da onerosidade e da subordinação.

No segundo capítulo, é abordado o fenômeno da "Uberização". Apresenta-se o funcionamento da empresa Uber e são analisadas as transformações do capitalismo no meio ambiente digital, com especial atenção à economia de compartilhamento e às novas formas de trabalho emergentes.

No terceiro capítulo, passa-se à abordagem jurisprudencial, com a análise de casos paradigmáticos internacionais e nacionais. No âmbito internacional, comenta-se acerca do Caso Dynamex, nos Estados Unidos; da decisão do Tribunal de Justiça da União Europeia (TJUE), no caso Elite Taxi 
versus Uber; e da decisão do Tribunal do Trabalho do Reino Unido, no caso Aslam versus Uber. Na seara nacional, destacam-se as decisões no TRT da $3^{\mathrm{a}}$ Região. Por fim, são feitas considerações finais. 


\section{CAPÍTULO I - OS ELEMENTOS FÁTICO-JURÍDICOS CARACTERIZADORES DA RELAÇÃO DE EMPREGO}

\subsection{Trabalho versus Emprego}

Antes de serem apresentados os pressupostos da relação empregatícia, impende seja a relação de trabalho diferenciada da relação de emprego. "Trabalho" denota qualquer relação jurídica de obrigação de fazer de labor humano. Trata-se de gênero ao qual pertencem diferentes espécies de prestação de labor como o emprego, o trabalho avulso, o trabalho eventual, o estágio, dentre outras.

Diversamente, "emprego" é a espécie de trabalho que se enquadra nos elementos fático-jurídicos ou pressupostos previstos nos artigos $2^{\circ}$ e $3^{\circ}$ da CLT $^{6}$. É dizer: (i) prestado por pessoa física; (ii) com pessoalidade; (iii) com habitualidade ou não eventualidade; (iv) com onerosidade; e (v) com subordinação.

Observada a cumulação de tais elementos, Amauri Mascaro Nascimento, concisa e precisamente, define o empregado como "a pessoa física que, com ânimo de empregado, trabalha subordinadamente e de modo não-eventual para outrem, de quem recebe salário."

\footnotetext{
${ }^{6}$ Art. $2^{\circ}$, CLT - Considera-se empregador a empresa, individual ou coletiva, que, assumindo os riscos da atividade econômica, admite, assalaria e dirige a prestação pessoal de serviço.

Art. $3^{\circ}$, CLT - Considera-se empregado toda pessoa física que prestar serviços de natureza não eventual a empregador, sob a dependência deste e mediante salário.
}

${ }^{7}$ NASCIMENTO, Amauri Mascaro. Op. Cit., p. 613. 


\subsection{Trabalho prestado por pessoa física}

$\mathrm{O}$ artigo $3^{\circ}$ da CLT expressamente prevê que o empregado deve ser pessoa física ("considera-se empregado toda pessoa física..."). A redação do referido dispositivo reflete a ideia de que o trabalho é obrigação de fazer indissociável da pessoa humana, a quem o ordenamento jurídico se refere, na qualidade de ente jurídico, como "pessoa natural". ${ }^{8}$ Dessa forma, para a caracterização da obrigação de labor como emprego, sua pactuação e prestação devem ser feitas por pessoa física ou natural.

A pessoa jurídica, compreendida como o agrupamento de pessoas humanas com uma finalidade econômica ou social específica ${ }^{9}$, pode figurar como empregador, mas, para fins de tutela das leis trabalhistas, jamais como empregado.

Assim, não raro se observa, como forma de atrair a incidência da legislação civil e esquivar-se do pagamento das verbas trabalhistas, a atribuição da forma de pessoa jurídica à serviços materialmente prestados por pessoas físicas nas condições dos artigos $2^{\circ}$ e $3^{\circ}$ da CLT - prática fraudulenta e recorrente no fenômeno da "pejotização" ${ }^{10}$.

\footnotetext{
8 "Pessoa natural" e "pessoa física" são expressões sinônimas. Vale ressaltar, no entanto, a preferência do civilista Caio Mário pela primeira. $\mathrm{O}$ autor entende que a palavra "natural" remete à tutela do direito em todos os aspectos da pessoa humana - físicos, materiais e, também, morais. PEREIRA, Caio Mário da Silva. Instituições de Direito Civil. Vol. I. Introdução ao Direito Civil. $32^{\mathrm{a}}$ ed. Rio de Janeiro: Forense. 2019. p. 613.

${ }^{9}$ Ibid. p. 181.

${ }^{10}$ A "pejotização" é transformação dos contratos de trabalho, regidos pela CLT, em contratos de prestação de serviço entre pessoas jurídicas. Ainda que, por si só, não constitua crime, é comumente usada para mascarar a realidade material do vínculo de emprego. OLIVEIRA, Fábio. Como evitar fraudes no processo de pejotização. Disponível em <https://www.gazetadigital.com.br/colunas-eopiniao/colunas-e-artigos/como-evitar-fraudes-no-processo-de-pejotizao/585028 $>$. Acesso em 14.nov.19.
} 


\subsection{Trabalho prestado com pessoalidade}

Como adverte Maurício Godinho Delgado, a pessoalidade não se confunde com o requisito da prestação de labor por pessoa física, pois é possível que o trabalho seja desempenhado por pessoa física sem que se cumpra o requisito da pessoalidade ${ }^{11}$.

Este elemento exigido ao liame empregatício encontra previsão no artigo $2^{\circ}$ da CLT, que define o empregador. A norma positiva que o empregador é aquele que "(...) admite, assalaria e dirige a prestação pessoal de serviço." (grifo nosso). Dessa forma, a pessoalidade pode ser observada tanto pela perspectiva do empregador como da do empregado - sendo esta a mais comumente adotada.

Sob o prisma do empregado, a pessoalidade equivale a dizer que o contrato de trabalho ou a obrigação por ele pactuada tem caráter infungível, indelegável ou, ainda, intuitu personae. Mormente porque, conforme elucida Carmen Carmino, o objeto do contrato de trabalho é o ato de trabalhar em si e não o resultado do trabalho ${ }^{12}$. Nesse sentido, Vólia Bomfim Cassar corrobora que a infungibilidade incide sobre o contrato de trabalho quando este especifica a obrigação laboral como personalíssima ${ }^{13}$.

No silêncio do contrato quanto à natureza personalíssima da obrigação pactuada, o prestador pode ser substituído por alguém escolhido pelo empregador - em razão de faltas, férias, atrasos ou por mera substituição.

\footnotetext{
${ }^{11}$ DELGADO, Maurício Godinho. Op. Cit., p. 283.

${ }^{12}$ CAMINO, Carmen. Direito Individual do Trabalho. 4. Ed. Porto Alegre: Síntese, 2004. p. 194. apud ALT, Verônica Rossa. Análise Jurídica da Prestação de Trabalho do Motorista por Aplicativos de Transporte Urbano: O Caso Uber. Tese (Trabalho de Conclusão de Curso de Graduação) Universidade Federal do Rio Grande do Sul, Faculdade de Direito, Curo de Ciências Jurídicas e Sociais. Porto Alegre, 2017. p. 19.

${ }^{13}$ CASSAR, Vólia Bomfim. Direito do Trabalho. $11^{\mathrm{a}}$ ed. Rio de Janeiro: Forense; São Paulo: MÉTODO, 2015. p. 243.
} 
Contudo, é vedado que o empregado se faça substituir por alguém de sua própria escolha ou sem o consentimento do empregador.

Amauri Mascaro Nascimento, neste ponto, considera o objeto do contrato de trabalho tanto a prestação como o prestador, entendendo-os como elementos indissociáveis. Por essa dimensão, compreende que a pessoalidade dá ensejo à proteção aos direitos da personalidade do empregado e à um dever de lealdade deste para com o empregador, também dimensões da pessoalidade.

A pessoalidade permeia toda a duração da relação de emprego, desde a sua constituição até a sua extinção. $\mathrm{Na}$ sua instituição, o empregado é selecionado pelo empregador, através de testes e dinâmicas planejadas para identificar requisitos específicos, por ser avaliado como apto a oferecer as qualidades laborais desejadas.

No decorrer da execução do contrato, salvo exceções como férias, licenças, interrupções e suspensões de contrato admitidas ${ }^{14}$, é inviável que a prestação do serviço seja feita por empregado outro que não o contratado. A substituição do empregado acarreta em uma nova relação jurídica do substituto com o empregador ${ }^{15}$.

Ainda, na extinção da relação laboral, a pessoalidade impede que, na morte do empregado, as obrigações personalíssimas contraídas sejam transmitidas à herdeiros e sucessores ${ }^{16}$.

Já pelo prisma do empregador, a pessoalidade adota a diretriz da despersonalização do empregador, como explica Maurício Godinho Delgado $^{17}$. Prioriza-se a manutenção do vínculo de emprego em detrimento das qualificações do empregador, permitindo que em caso de sucessão de

\footnotetext{
${ }^{14}$ DELGADO, Maurício Godinho. op. cit. p. 283

${ }^{15}$ Ibid. p. 284.

${ }^{16}$ Ibid. p. 284.

${ }^{17}$ Ibid. p. 284.
} 
empregadores (artigos $10^{18}$ e $448^{19}$ da CLT) os empregados mantenham seus contratos de trabalho e direitos adquiridos.

\subsection{Trabalho prestado com não eventualidade, ineventualidade ou habitualidade}

$\mathrm{O}$ artigo $3^{\circ}$ da CLT determina que a natureza do serviço prestado pelo empregado ao empregador há de ser "não eventual". Em termos gerais, isto equivale a um serviço prestado de forma permanente e contínua. Mas como pergunta José Martins Catharino, "Eventual de que e de quem? Do trabalho prestado por determinado trabalhador ou da atividade do empregador?"20.

É tarefa de vasta controvérsia doutrinária a definição de critérios que permitam identificar a habitualidade no caso concreto. Desta forma, quatro teorias foram elaboradas ${ }^{21}$ : (i) a teoria da descontinuidade; (ii) a teoria da fixação jurídica; (iii) a teoria dos fins do empreendimento; e (iv) a teoria do evento.

A teoria da descontinuidade considera como eventual o trabalho que o tomador recebe, de um mesmo empregado, de forma descontínua e espaçada no tempo. Ainda que não encontre albergue na CLT, mostra-se compatível com a legislação do trabalho doméstico.

\footnotetext{
${ }^{18}$ Art. 10, CLT - Qualquer alteração na estrutura jurídica da empresa não afetará os direitos adquiridos por seus empregados.

${ }^{19}$ Art. 448, CLT - A mudança na propriedade ou na estrutura jurídica da empresa não afetará os contratos de trabalho dos respectivos empregados.

${ }^{20}$ CATHARINO, José Martins. Compêndio Universitário de Direito do Trabalho. São Paulo: Editora Jurídica e Universitária, 1972, p. 185 apud CASSAR, op. cit. p. 259.

${ }^{21}$ Os autores divergem sobre qual teoria deve ser adotada na análise da habitualidade. Maurício Godinho Delgado, à exceção da teoria da descontinuidade, entende que todas as demais correntes devem ser aplicadas. Vólia Bomfim Cassar discorda, pois entende ser impossível a cumulação das teorias. A autora ensina que a não eventualidade deve ser apurada a partir da "necessidade permanente" da empresa, se aproximando, assim, da lógica da teoria dos fins do empreendimento. Já Amauri Mascaro Nascimento, encontra-se filiado à teoria da fixação jurídica.
} 
Isto, porque a Lei Complementar 150/15, no seu artigo $1^{\text {o22 }}$, usa a expressão "serviços de forma contínua" para se referir ao elemento da não eventualidade no caso dos empregados domésticos. Segundo Maurício Godinho Delgado, em razão da preocupação legislativa de diferenciar o empregado doméstico e o trabalhador eventual doméstico (conhecido como "diarista") $)^{23}$.

Diversamente da LC 150/15, a CLT emprega a locução "não eventual" no seu artigo $3^{\circ}$ para se referir à habitualidade. Conquanto referida expressão não descaracterize a necessidade de uma prestação laboral permanente como requisito à configuração do emprego, indica que essa permanência não se confunde com intermitência, podendo ser fracionada no tempo ${ }^{24}$.

A teoria da fixação jurídica, à qual se filia Amauri Mascaro Nascimento, associa eventualidade à fixação jurídica do trabalhador na empresa, sendo eventual aquele que não é fixado juridicamente. $\mathrm{O}$ autor define como eventual:

“(...) aquele que presta sua atividade para múltiplos destinatários, sem se fixar continuamente em nenhum deles. Eventual é um subordinado de poucas horas ou pouco tempo que vai realizar um serviço especificado, findo o qual terminará a sua obrigação. Não é autônomo porque está sobre o poder diretivo de outrem, o destinatário do serviço enquanto o executar. Se o serviço for prestado sem a subordinação, será autônomo, provavelmente empreiteiro"25. (grifo nosso)

A teoria dos fins do empreendimento associa habitualidade à compatibilidade do serviço prestado pelo trabalhador com os fins da empresa, já que serviços compatíveis com os fins normais do negócio tendem a perdurar. Vólia Bomfim Cassar se aproxima desta teoria, mas critica o termo "fins normais" da empresa e prefere a ideia de compatibilidade com a "necessidade permanente" da empresa, seja em atividade-fim ou meio, de

\footnotetext{
${ }^{22}$ Art. $1^{\circ}$, LC 150/15 - Ao empregado doméstico, assim considerado aquele que presta serviços de forma contínua, subordinada, onerosa e pessoal e de finalidade não lucrativa à pessoa ou à família, no âmbito residencial destas, por mais de 2 (dois) dias por semana, aplica-se o disposto nesta Lei.

${ }^{23}$ DELGADO, Maurício Godinho. op. cit. p. 318.

${ }^{24}$ Ibid. p. 319.

${ }^{25}$ NASCIMENTO, Amauri Mascaro. Op. Cit., p. 626.
} 
forma contínua ou intermitente. Eventual, a contrario sensu, seria a necessidade acidental, ainda que repetida no tempo.

José Martins Catharino, citado por Vólia Bomfim Cassar ${ }^{26}{ }_{0.0 B j}$, explica que:

"Duas correntes principais existem quanto à caracterização da eventualidade. $\mathrm{Na}$ Itália predomina o critério da descontinuidade ou da falta de profissionalidade do trabalho prestado por determinado trabalhador. No México e no Brasil, segue-se o da natureza do trabalho em função da atividade da empresa. Como a doutrina e a jurisprudência nacionais o adotam pacificamente, vindo do México, vale a pena transcrever trecho de uma decisão, de 03.09.1936, da Suprema Corte Mexicana: 'para a existência de um trabalho efetivo requer-se unicamente que o serviço desempenhado constitua uma necessidade permanente da empresa, isto é, que não se trate de um serviço meramente acidental, cuja repetição só possa ser consequência do concurso de circunstâncias especiais, ou, igualmente, que o serviço não faça parte das atividades normais constantes e uniformes da empresa..."'.

Por fim, a teoria do evento reputa eventual a prestação de serviço pactuada para um evento fortuito e pontual que não se prolonga no tempo. Vólia Bomfim Cassar a critica no sentido de que, ainda que curto, o serviço pode constituir uma necessidade permanente intermitente (como ocorre com o Natal, uma colheita ou uma coleção nova, por exemplo).

\subsection{Trabalho prestado com onerosidade}

Através do contrato de trabalho o empregado voluntariamente cede ao empregador a titularidade dos frutos do seu trabalho. Como resultado, o empregado se exime dos riscos e das incertezas do resultado futuro do seu trabalho, que são assumidos pelo empregador, conforme preceitua o artigo $2^{\circ}$ da CLT. Ademais, passa a receber deste uma percepção presente e regular: o salário.

Sua etimologia deriva do latim "salarium" que, por sua vez, deriva da palavra "sal", e remete-nos à prática romana de usar o sal como mercadoria-

\footnotetext{
${ }^{26}$ CATHARINO, José Martins. op. cit. p. 185 apud CASSAR, op. cit. p. 260.
} 
moeda para remunerar os trabalhadores ${ }^{27}$. O salário - em pecúnia ou utilidade - representa, portanto, a contraprestação do empregador à alienação feita pelo empregado dos resultados da sua mão-de-obra ${ }^{28}$. A onerosidade, desta forma, se consubstancia em uma reciprocidade de vantagens, como um encargo bilateral.

A identificação deste elemento perpassa duas dimensões, segundo Maurício Godinho Delgado ${ }^{29}$ : uma objetiva e outra subjetiva. No plano objetivo, a onerosidade ocorre com o pagamento do salário que, em observação ao artigo 459 da CLT $^{30}$, pode ser estipulado em diferentes periodicidades desde que não superior a um mês. No plano subjetivo, se refere ao ânimo (animus contrahendi) ${ }^{31}$ do prestador de serviço de trabalhar para outrem com o objetivo de auferir um ganho econômico pelo serviço prestado.

Neste ponto, Amauri Mascaro Nascimento, citando Arnaldo Sussekind, aponta que ${ }^{32}$ :

“(...) não é a falta de estipulação do quantum do salário ou o seu pagamento sob a forma indireta, que desfiguram a condição de empregado, e sim a intenção de prestar o serviço desinteressadamente, por mera benevolência".

Por isso, no cenário de falta de estipulação do salário, o artigo 460 da $\mathrm{CLT}^{33}$ determina que o empregado perceba igual salário àquele que, na

\footnotetext{
${ }^{27}$ ALT, Verônica Rossa. op. cit. p. 17.

${ }^{28}$ DELGADO, Maurício Godinho. op. cit. p. 322.

${ }^{29}$ Ibid. p. 322.

${ }^{30}$ Art. 459, CLT - O pagamento do salário, qualquer que seja a modalidade do trabalho, não deve ser estipulado por período superior a 1 (um) mês, salvo no que concerne a comissões, percentagens e gratificações.

$\S 1^{\circ}$ Quando o pagamento houver sido estipulado por mês, deverá ser efetuado, o mais tardar, até o quinto dia útil do mês subsequente ao vencido.

31 Alguns autores optam pelos termos "profissionalidade" e "produtividade" em detrimento de "ânimo" com o fim de denotar que o objeto de proteção do Direito do Trabalho é apenas o trabalho produtivo, excluído o benevolente. NASCIMENTO, Amauri Mascaro. Op. Cit., p. 627.

${ }^{32}$ Ibid. p. 629

33 Art. 460, CLT - Na falta de estipulação do salário ou não havendo prova sobre a importância ajustada, o empregado terá direito a perceber salário igual ao daquela que, na mesma empresa, fizer serviço equivalente ou do que for habitualmente pago para serviço semelhante.
} 
mesma empresa, opera serviço equivalente ou do que for habitualmente se paga para serviço semelhante.

\subsection{Trabalho prestado com subordinação jurídica}

O pressuposto da subordinação é citado de forma recorrente como o mais importante na identificação da relação de emprego, ainda que todos os elementos anteriormente expostos tenham que também estar presentes para a configuração do emprego.

Sem embargo, a legislação celetista não faz uso do termo "subordinação" em seu texto. O artigo $3^{\circ}$ da CLT emprega a palavra "dependência". A subordinação é, portanto, uma construção doutrinária e jurisprudencial que responde à necessidade do Direito do Trabalho de determinar uma espécie de trabalho ou trabalhador como objeto de tutela ${ }^{34}$.

Derivada do latim sub (baixo) e ordinare (ordenar), a palavra subordinação remete a uma submissão ao poder de outrem. Maurício Godinho Delgado compreende este elemento como uma situação jurídica, resultante do contrato de trabalho, que confere ao empregador um poder diretivo e que se transmuta, para o empregado, em uma limitação à sua autonomia da vontade, em um estado de obediência quanto à forma da prestação do seu serviço ${ }^{35}$.

Vólia Bomfim Cassar complementa o entendimento de Maurício Godinho Delgado opinando que há uma variação na intensidade da subordinação de acordo com a natureza do trabalho prestado. ${ }^{36}$

\footnotetext{
${ }^{34}$ GASPAR, Danilo Gonçalves. A Crise da Subordinação Jurídica Clássica enquanto elemento definidor da relação de emprego e a proposta da subordinação potencial. Dissertação de Mestrado. Universidade Federal da Bahia, Faculdade de Direito. Salvador, 2011. p. 113.

${ }^{35}$ DELGADO, Maurício Godinho. op. cit. p. 325.

${ }^{36}$ CASSAR, Vólia Bomfim. op. cit., p. 247.
} 


\subsubsection{A natureza da subordinação}

Para Maurício Godinho Delgado, é pacífico que a natureza da subordinação seja jurídica, pois consubstancia-se em um estado de dependência voluntária do empregado, quanto ao modo de prestação do seu serviço, em razão do direito do empregador de dirigir a atividade ${ }^{37}$. Ambas premissas advindas do instrumento jurídico do contrato de trabalho, onde a subordinação encontra seu fundamento.

Conforme Amauri Mascaro do Nascimento afirma:

“(...) a subordinação encontra o seu fundamento no contrato de trabalho, significando uma limitação à autonomia do empregado, porém em decorrência da sua própria vontade ao se propor a prestar serviços sob o poder de direção de outrem. " 38

Não obstante, por algum tempo se debateram possíveis naturezas econômica e técnica para este elemento ${ }^{39}$, que merecem ser exploradas diante de avanços tecnológicos capazes de minar ideias até então consolidadas ${ }^{40}$. Ocorre que, ainda que ambos modos de subordinação possam ser comumente observados nas relações de trabalho, não são uma regra absoluta e consistem em elementos metajurídicos, externos à relação jurídica, que não interferem nos aspectos jurídicos do contrato de trabalho. ${ }^{41}$

A teoria da subordinação econômica, advinda da doutrina alemã $\tilde{a}^{42}$, projeta na relação de emprego a assimetria econômica que tradicionalmente separa o tomador do obreiro. Maurício Godinho Delgado aponta que, embora seja uma formulação sociologicamente válida, afinal a origem do Direito do

\footnotetext{
${ }^{37}$ DELGADO, Maurício Godinho. op. cit. p. 326.

${ }^{38}$ NASCIMENTO, Amauri Mascaro. Curso de Direito do Trabalho. 20. ed. São Paulo: Saraiva, 2005. p. 602. apud GASPAR, Danilo Gonçalves. op. cit. p. 120.

${ }^{39}$ Ibid. p. 326.

${ }^{40}$ ALT, Verônica Rossa. op. cit. p. 22.

${ }^{41}$ DELGADO, Maurício Godinho. op. cit. p. 326.

${ }^{42}$ GASPAR, Danilo Gonçalves. op. cit. p. 115.
} 
Trabalho remonta à essa discrepância econômica no contexto do trabalho como meio garantidor da subsistência, falha juridicamente.

Como observa Danilo Gonçalves Gaspar em sua dissertação de mestrado, essa teoria falha porque, em primeiro lugar, o emprego prescinde de exclusividade. Trabalhadores podem ter múltiplos empregos e dependerem economicamente de cada um de seus contratantes. Nesse cenário, a teoria da subordinação econômica absoluta falharia, pois, como nenhum dos tomadores absorveria o obreiro de forma integral, seria inviável distinguir de quem o prestador dependeria economicamente. Se relativizada, a dependência econômica seria imputada ao tomador que representasse a maior absorção e principal meio de subsistência ${ }^{43}$.

Em que pese a possibilidade de relativização, ocorre que, existem empregados independentes economicamente de seus empregadores ${ }^{44}$. É possível prestar um serviço por mera satisfação e prazer, sem que a subsistência seja um motivador. Maurício Godinho Delgado reforça essa crítica e aponta que a diferença econômico-social entre tomador e prestador não se traduz em um feixe jurídico de mesma discrepância no contrato de trabalho ${ }^{45}$.

Já a teoria da subordinação técnica, atribuída à Sociedade de Estudos Legislativos da França, reflete uma suposta desigualdade de conhecimento técnico entre o tomador e o obreiro na relação de emprego. Considera que o empregador monopoliza a orientação e a direção técnicas do processo de produção e, por isso, deteria poder sobre a prestação de serviço do empregado. ${ }^{46}$

É uma teoria falha, pois, como nota Maurício Godinho Delgado, o processo produtivo atual é controlado pelo tomador por meio de instrumentos jurídicos - e não intelectuais. É justamente pelo fato de o empregador não

\footnotetext{
${ }^{43}$ Ibid. p. 116-117.

${ }^{44}$ Ibid. p. 115.

${ }^{45}$ DELGADO, Maurício Godinho. op. cit. p. 327.

${ }^{46}$ GASPAR, Danilo Gonçalves. op. cit. p. 113.
} 
deter a total sabedoria técnica da produção que seleciona obreiros que a tenham ${ }^{47}$. Por isso, trabalhadores especializados, técnicos ou intelectuais, capazes de tomar decisões próprias quanto à execução de seus trabalhos, não deixam de ser classificados como empregados.

\subsubsection{Dimensões da subordinação}

Fato é que a dinâmica laboral se encontra em constante mutação. De forma que a normatização jurídica, para conferir a devida regulamentação e proteção aos seus tutelados, também deve mostrar-se adaptável. Por isto, Maurício Godinho Delgado propõe que a subordinação seja apreendida na realidade fática a partir da conjugação de três dimensões: uma clássica, uma objetiva e uma estrutural ou integrativa ${ }^{48}$.

A dimensão clássica da subordinação é a forma mais incipiente de subordinação e a mais comumente identificada. Maurício Godinho Delgado a define como uma:

“ (...) situação jurídica derivada do contrato de trabalho, pelo qual o trabalhador compromete-se a acolher o poder de direção empresarial no tocante ao modo de realização de sua prestação laborativa. Manifesta-se pela intensidade de ordens do tomador de serviços sobre o respectivo trabalhador." 49

A dimensão estrutural ou integrativa da subordinação se evidencia na mera inserção do empregado na estrutura empresarial, independente do recebimento de ordens diretas e da intensidade ou natureza do serviço prestado $^{50}$.

A dimensão objetiva da subordinação, de maior recepção pela doutrina e jurisprudência pátrias, se manifesta através da integração do trabalhador nos fins do negócio do tomador. Arion Sayão Romita e Vólia

\footnotetext{
${ }^{47}$ DELGADO, Maurício Godinho. op. cit. p. 327.

${ }^{48}$ Ibid. p. 327.

${ }^{49}$ Ibid. p. 327.

${ }^{50}$ Ibid. p. 328.
} 
Bomfim Cassar filiam-se à esta concepção de subordinação de Maurício Godinho Delgado, mas através de outra classificação: a de subordinação objetiva versus subjetiva.

Os autores defendem a matriz objetiva da subordinação e destacam que a palavra "dependência", no artigo $3^{\circ}$ da CLT, bem como a exigência de pessoalidade da prestação do serviço, pelo artigo $2^{\circ}$ da CLT, não significam uma subordinação subjetiva ou pessoal ou, ainda, um status do trabalhador ${ }^{51}$.

Nesse cenário, majoritariamente adotado no Brasil, o obreiro permanece como um indivíduo em suas relações sociais. De forma que não é a sua pessoa que se insere na estrutura do tomador, mas é o seu trabalho que se integra à empresa. Nesse sentido, Amauri Mascaro Nascimento observa uma indissociabilidade da prestação e do prestador de serviço ${ }^{52}$ - o que torna possível a subordinação de trabalhadores em domicílio, por exemplo ${ }^{53}$.

\footnotetext{
${ }^{51}$ CASSAR, Vólia Bomfim. op. cit. p. 249.

${ }^{52}$ NASCIMENTO, Amauri Mascaro. op. cit. p. 617.

${ }^{53}$ ALT, Verônica Rossa. op. cit. p. 26.
} 


\section{CAPÍTULO II - CARACTERÍSTICAS E REFLEXOS DO FENÔMENO DA "UBERIZAÇÃO" NAS RELAÇÕES DE TRABALHO}

\subsection{A nova base técnica do capitalismo no meio ambiente digital e o consumo colaborativo}

No livro Homo Sapiens - Uma Breve História da Humanidade, o historiador israelense Yuval Noah Harari traça a narrativa da evolução humana, do surgimento do Homo Sapiens como espécie até a sua consolidação como única espécie de Hominídeo a dominar o planeta.

$\mathrm{O}$ autor aponta que o primeiro aumento exponencial da produção per capita mundial foi na Era Moderna em razão, além de matéria-prima e energia disponíveis, de dois elementos basilares do sistema capitalista: a confiança no futuro e o reinvestimento dos lucros na produçãa ${ }^{54}$.

O primeiro elemento, associado à invenção do crédito, que torna possível a representação de bens imaginários, permite a construção do presente às custas do futuro. A crença no progresso, instigada pela Revolução Científica, intensificou a confiança em um futuro promissor e, consequentemente, aumentou o crédito disponível e trouxe acessibilidade imediata à bens e serviços.

$\mathrm{O}$ segundo elemento remete à prescrição capitalista de que o capital (dinheiro, bens e recursos), diferente da mera riqueza, que é desperdiçada em atividades improdutivas, deve ser reinvestido na produção para que se aumentem a riqueza e a propriedade coletivas.

\footnotetext{
${ }^{54}$ Harari, Yuval Noah. Sapiens - Uma breve história da humanidade. $28^{\mathrm{a}}$ Ed. Porto Alegre, RS: L\&PM, 2017. p.315.
} 
Essa estrutura basilar capitalista, mais que uma teoria econômica, se consolidou como uma ética. Tornou-se uma conduta de pensamento e comportamento que aliou o crescimento econômico à promoção do bem comum, de forma direta ou indireta.

No entanto, uma mudança na base técnica desse capitalismo é apontada por Josiane Caldas Kramer, em sua dissertação de mestrado, como resultado da Revolução Tecnológica ${ }^{55}$. As novas formas de comunicação e a automatização entram em cena para mudarem o relacionamento das pessoas com o mercado.

Quanto ao primeiro aspecto, notam-se comunicações mais horizontais e velozes, que culminam em perspectivas temporais e espaciais diferentes. Quanto ao segundo, observa-se a automatização de atividades manuais de diferentes complexidades, que resultam, em larga escala, na substituição da mão-de-obra humana pela máquina - impulsionando o fenômeno do desemprego estrutural.

Essa nova base técnica capitalista identificada por Josiane Caldas Kramer é a mola propulsora da chamada "economia compartilhada", gig economy ou sharing economy. ${ }^{56}$

\footnotetext{
55 A Revolução Tecnológica, tida como uma Terceira Revolução Industrial é marcada pela microeletrônica, que permite a invenção dos celulares e computadores e, com eles, da internet. Nas palavras de Kramer, "A introdução do microchip tem a mesma relevância nesta transformação que teve a máquina a vapor, a eletricidade e a linha de montagem em outros períodos, um avanço ímpar no desenvolvimento da tecnologia na história da humanidade.”. KRAMER, Josiane Caldas. A Economia Compartilhada e a Uberização do Trabalho: Utopias do Nosso Tempo? Paraná, 24.03.17. p. 51. Dissertação / UFPR. Disponível em <https://acervodigital.ufpr.br/bitstream/handle/1884/47786/R\%20-\%20D\%20\%20JOSIANE\%20CALDAS\%20KRAMER.pdf?sequence=1 >. Acesso em 23.out.18.

56 Em 2015 o dicionário de Oxford incluiu oficialmente a expressão shared economy em suas definições como "an economic system that is based on people sharing possessions and services, either for free or for payment, usually using the internet to organize this" / "Um sistema econômico no qual pessoas compartilham bens e serviços, de forma gratuita ou onerosa, tipicamente através da Internet." (tradução nossa). Disponível em <https://dictionary.cambridge.org/us/dictionary/english/sharing-economy>. Acesso em 21.out.19.
} 
Rachel Botsman, especialista em tecnologia e professora da Universidade de Oxford, aponta a "economia de compartilhamento" como um modelo econômico fundado no compartilhamento de bens e serviços subutilizados, gratuito ou oneroso, promovido diretamente pelos indivíduos ${ }^{57}$.

A autora ainda distingue o modelo de compartilhamento da economia colaborativa e da economia sob demanda. Porém, o faz como voz singular, pois, em geral, os autores associam a economia de compartilhamento ao padrão de consumo colaborativo em si.

Define a economia colaborativa como o modelo que, apesar de também explorar bens subutilizados, opera por redes descentralizadas, em substituição à tradicional figura centralizadora do intermediário, que combinam oferta e demanda. Já a economia sob demanda, engloba plataformas que combinam de forma direta as necessidades do consumidor e do prestador para permitir a imediata fruição do bem ou serviço. Para a autora, seria este o caso da Uber.

Conforme entendimento majoritário, distinções à parte, todos esses modelos representam um novo padrão comportamental de consumo de mercado no meio ambiente digital pautado pela colaboração. Um movimento no qual se privilegia o acesso em detrimento da posse e se otimiza a utilidade da propriedade pelo compartilhamento de excedentes. Nota-se que não se trata de um compartilhamento "forçado e educado", porquanto opera sem perda de liberdades e sem que as pessoas comprometam seu estilo de vida. ${ }^{58}$

Nesse sentido, como exposto por Josiane Caldas Kramer, a economia de compartilhamento pode ser satisfatoriamente definida como:

\footnotetext{
${ }^{57}$ Trata-se de entrevista de Rachel Botsman, professora da Universidade de Oxford e autora de livros de economia e tecnologia. Disponível em < https://www.fastcompany.com/3046119/defining-thesharing-economy-what-is-collaborative-consumption-and-what-isnt $>$. Acesso em 21.out.19.

${ }^{58}$ BOTSMAN, R.; ROGERS, R. O que é meu é seu: como o consumo colaborativo vai mudar o nosso mundo. Porto Alegre: Bookman, 2011. apud KRAMER, op. cit., p. 56.
} 
“(...) uma nova etapa no processo de desenvolvimento econômico, simbolizado pela superação da lógica de consumo em massa e visando ao acúmulo de bens, típica do final do último século, por um momento em que o mercado, já saturado por crises financeiras e pautado por necessidades ligadas à sustentabilidade e ao uso racional dos bens, passa a privilegiar novas formas de acesso a bens e a serviços. Em última instância, a economia do compartilhamento está baseada no uso de tecnologia da informação em prol da otimização do uso de recursos através de sua redistribuição, compartilhamento e aproveitamento de suas capacidades excedentes." 59

Ou ainda como:

“(...) um conjunto de iniciativas de consumo conectado, que prioriza a reutilização de bens e as chamadas conexões peer-to-peer, eliminando desta maneira os intermediários e, possibilitando o contato frente a frente, pessoal, além de possibilitar uma nova conformação na forma de fazer negócios na economia tradicional." 60

As vantagens do consumo colaborativo são inegáveis. Um estudo do CADE, de 2018, apontou que enquanto consumidores encontram maior variedade de opções de consumo à preços mais baixos, ofertantes têm acesso mais fácil e eficiente ao mercado de consumo e menor ociosidade para seus bens ${ }^{61}$.

Outras, notadas por Rachel Botsman, perpassam a democratização no acesso à bens e serviços ${ }^{62}$, a redução dos impactos ambientais da atividade produtiva, a diluição da concentração de receitas, a formação de um sentimento de comunidade e a passagem do poder de instituições centralizadoras para redes de indivíduos.

Neste último aspecto, Josiane Caldas Kramer atenta para o fato de que, mesmo no compartilhamento, a maior parcela de poder fica concentrado nas grandes empresas. Isto ocorre porque, sendo o acesso o bem maior dessa

\footnotetext{
${ }^{59}$ SOUZA E LEMOS, 2016, p. 1759 apud KRAMER, Ibid, p. 55.

${ }^{60}$ DUBOIS et al. Connected consumption: a sharing economy takes hold. Rotman Management: 2014, pp. 50-55. apud KRAMER, Ibid. p. 57.
}

${ }^{61}$ MAGNANI, FEIGELSON e LOPES. Há vínculo de emprego entre entregadores e aplicativos?. JOTA. Disponível em $<$ https://www.jota.info/opiniao-e-analise/colunas/regulacao-e-novastecnologias/ha-vinculo-de-emprego-entre-entregadores-e-aplicativos-15062018\#sdfootnote1sym>. Acesso em 7.nov.19.

62 Pesquisa da empresa Statista revela que entre os usuários de aplicativos de transporte em 2018, $60 \%$ apresentam renda média e baixa. O diretor de comunicação da Uber para a América Latina revela que o maior crescimento da empresa é nas periferias dos grandes centros, regiões em que melhor se evidencia a falta de transporte adequado. Disponível em < https://www.ilocomotiva.com.br/single-post/2019/04/17/EXAME-A-Economia-dos-Apps $>$.

Acesso em 3.nov.19. 
economia, o poder maior resta com quem o detém - na Era Digital, as grandes plataformas tecnológicas como a Uber Technologies. Para Arun Sundararajan, trata-se de um "capitalismo baseado em multidão". ${ }^{63}$

Ilustra-se, portanto, um novo paradigma capaz de alterar o crescimento econômico e o futuro do trabalho de formas preocupantes. Não por outro motivo, no Congresso brasileiro já opera uma "bancada digital", empenhada na confecção de uma legislação principiológica para as plataformas de economia compartilhada ${ }^{64}$.

\subsection{A Uber como expoente do consumo colaborativo: como funciona a empresa}

A Uber Technologies Inc. é uma empresa multinacional norteamericana prestadora de serviços eletrônicos no setor de transporte. Seu pioneirismo se deve à tecnologia do E-hailing, que permite a requisição de transporte por meio de um dispositivo virtual - computador ou celular - com base na localização do requisitante.

Integra o segmento "online-to-offline" $(\mathrm{O} 2 \mathrm{O})$ da economia de compartilhamento, cujos negócios intermediam a oferta de bens e serviços por transações iniciadas na internet (online) e finalizadas no mundo físico com o recebimento do produto (offline) ${ }^{65}$.

\footnotetext{
${ }^{63}$ SUNDARARAJAN, Arun. The sharing economy: the end of employment and the rise of crowdbased capitalism. Cambridge, Massachusetts: The MIT Press, 2016 apud KRAMER, Op. Cit. p. 57.

64 TREVOR, Valentina. Deputado defende lei principiológica para plataformas de economia compartilhada. Disponível em <https://www.jota.info/coberturas-especiais/economiacompartilhada/lei-principiologica-economia-compartilhada-09092019>. Acesso em 7.nov.19

${ }^{65}$ MAGNANI, FEIGELSON e LOPES. Há vínculo de emprego entre entregadores e aplicativos?. JOTA. Disponível em <https://www.jota.info/opiniao-e-analise/colunas/regulacao-e-novastecnologias/ha-vinculo-de-emprego-entre-entregadores-e-aplicativos-15062018\#sdfootnote1sym>. Acesso em 7.nov.19.
} 
O conceito da empresa foi idealizado em 2009, quando os fundadores Garett Camp e Travis Kalanick, ao participarem de uma conferência em Paris, encontraram dificuldades em pegar um táxi na volta para o hotel. $\mathrm{Na}$ ocasião, pensaram em como seria bom poder alugar os serviços de um motorista particular com um simples toque no celular.

Foi no ano seguinte, em 5 de julho de 2010, na cidade de São Francisco, Estado da Califórnia, nos Estados Unidos, quando o primeiro passageiro fez um "pedido de corrida" pelo aplicativo da Uber. Desde então, a empresa se expandiu para mais de 700 cidades em 63 países, conquistou 91 milhões de clientes e 3.9 milhões de motoristas mensalmente ativos, e contabilizou 10 bilhões de viagens no mundo todo (sendo, em média, 14 milhões de viagens por dia ${ }^{66}$.

Inicialmente planejada como uma plataforma para compartilhamento exclusivo de caronas - não por outro motivo adotava, embrionariamente, a razão social de UberCab -, hoje a empresa é uma plataforma única e total para a mobilidade e reúne diferentes empresas relacionadas à locomoção (de pessoas, coisas e comidas).

Seus produtos internacionais incluem o UberSUV: transporte em veículos com múltiplos lugares e conforto; o UberLUX: transporte em carros de marcas de luxo; o UberPOP: veículos compactos com preços abaixo do UberX; o UberRUSH: transporte em bicicletas; e o UberEATS: transporte de refeições de restaurantes e lanchonetes pedidas pelos usuários.

Na cidade de Denver, Estado do Colorado, nos Estados Unidos, a Uber já opera de forma integrada ao transporte público, sendo possível planejar uma rota integrando carro, patinete, ônibus e metrô. Em Miami e em Dubai, a empresa oferece transporte de barco ${ }^{67}$. E em 3 anos, projeta o lançamento

\footnotetext{
66 Dados de dezembro de 2018 disponíveis em <https://www.uber.com/pt$\mathrm{BR} /$ newsroom/informacoes-da-empresa/>. Acesso em 20.out.18.

${ }^{67}$ ROCHA, Caroline. Conheça 7 serviços diferentes que a Uber oferece pelo mundo. Olhar Digital. Disponível em <https://olhardigital.com.br/noticia/conheca-7-servicos-diferentes-que-a-uberoferece-pelo-mundo/62021>. Acesso em 21.out.19.
} 
do Uber Air, em parceria com as empresas aéreas Boeing e Embraer, que permitirá o transporte aéreo.

No Brasil, a Uber iniciou seus serviços em 2014, na cidade do Rio de Janeiro, por ocasião da Copa do Mundo. Atualmente, soma, no país, mais de 600 mil motoristas e 22 milhões de usuários distribuídos por 100 cidades $^{68}$. Atrás apenas dos Estados Unidos ${ }^{69}$, o Brasil é o segundo maior mercado da empresa $^{70}$ e a cidade de São Paulo detém o título de líder mundial de viagens, com 150 mil motoristas frequentemente ativos (em contraste a 38 mil taxistas cadastrados na cidade $)^{71}$.

São oferecidos oito serviços pela empresa no Brasil ${ }^{72}$ : (i) Uber X: transporte em carros compactos, com ar-condicionado e 4 portas por tarifas econômicas; (ii) UberX Vip: motoristas mais bem avaliados do UberX para os usuários que usam a Uber com mais frequência; (iii) Uber Juntos: transporte no qual usuários que estejam em trajetos similares podem dividir o mesmo carro; (iv) Uber Select: transporte em carros de qualidade e preço superiores ao Uber X; (v) Uber Black: transporte em carros sedã, com banco de couro e ar-condicionado por tarifas mais elevadas; (vi) Uber Comfort ${ }^{73}$ : transporte no qual o passageiro pode personalizar suas preferências de

\footnotetext{
${ }^{68}$ SALOMÃO, Karin. Os números secretos da Uber: US\$ 1 bi no Brasil, US\$ 11 bi no mundo. Disponível em < https://exame.abril.com.br/negocios/os-numeros-secretos-da-uber-us-1-bi-nobrasil-us-11-bi-no-mundo/>. Acesso em 20.out.18.

${ }^{69}$ KOJIKOVSKI, Gian. Após bonança, Uber vive momento inesperado no Brasil. Disponível em $<$ https://exame.abril.com.br/negocios/uber-o-dia-a-dia-de-uma-empresa-sob-pressao/>. Acesso em 23.out.18.

${ }^{70}$ LOBEL, Fabrício. Número de motoristas do Uber cresce dez vezes em um ano no Brasil. Disponível em <https://www1.folha.uol.com.br/cotidiano/2017/10/1931013-numero-demotoristas-do-uber-cresce-dez-vezes-em-um-ano-no-brasil.shtml>. Acesso em 23.out.18.

${ }^{71}$ DIÓGENES, Juliana. Total de carros da Uber e aplicativos supera número de taxistas em SP, diz Doria <https://sao-paulo.estadao.com.br/noticias/geral,total-de-carros-da-uber-e-outrosaplicativos-supera-numero-de-taxistas-em-sp-diz-doria,70001653256>. Acesso em 23.out.18

${ }^{72}$ Descubra as categorias de Uber e como podem te ajudar no dia a dia. Uber Blog. Disponível em <https://www.uber.com/pt-BR/blog/categorias-da-uber/>. Acesso em 7.nov.19.

${ }^{73}$ Uber anuncia nova categoria no Brasil que permite passageiro escolher se quer viagem sem conversa. G1. Disponível em <https://g1.globo.com/economia/tecnologia/noticia/2019/10/07/uberanuncia-nova-categoria-no-brasil-que-permite-passageiro-escolher-se-quer-viagem-semconversa.ghtml>. Acesso em 7.nov.19.
} 
temperatura e conversa com o motorista; (vii) Uber BAG: veículos que portamalas espaçoso para carregar malas; e (viii) Uber Eats: permite ao usuário solicitar refeições.

Para ser um motorista parceiro na cidade do Rio de Janeiro é necessário ter mais de 21 anos de idade e carteira de habilitação que autorize exercício de atividade remunerada (EAR). O veículo é cadastrado pela Certidão de Registro e Licenciamento (CRLV), pelo Comprovante de DPVAT do exercício corrente e por uma apólice de seguro contra acidentes pessoais a passageiros. Todo o cadastro é feito no site da $\mathrm{Uber}^{74}$.

Curiosamente, no vocabulário alemão Uber quer dizer algo incrível ou superior ${ }^{75}$. Pode-se dizer, assim, que a empresa fez, literalmente, jus ao seu nome, conforme nota Josiane Caldas Kramer, “(...) seja pela sua atuação em vários países, pelo volume de recursos que movimenta, ou pelos conflitos sociais e polêmicas já suscitadas ante a sua forma de estabelecer-se no mercado." 76

\subsection{O fenômeno da "Uberização"}

No mundo, aplicativos de transporte e de entrega de comida deverão passar dos 130 bilhões de dólares em faturamento em 2023. A China é a líder do mercado, seguida pela União Europeia e pelos Estados Unidos. No Brasil, as ferramentas de delivery de comida cresceram $20 \%$ em número de usuários em 2018, acima da média global, de 12\%. Em 2018, 18 milhões de brasileiros usaram regularmente aplicativos para ganhar algum dinheiro ${ }^{77}$.

\footnotetext{
74 Requisitos para os motoristas parceiros: como dirigir com a Uber. Disponível em $<$ https://www.uber.com/br/pt-br/drive/requirements/>. Acesso em 25.out.19.

${ }^{75}$ Disponível em < https://www.uber.com/pt-BR/blog/o-que-e-uber/>. Acesso em 23.out.19.

${ }^{76}$ KRAMER, Josiane Caldas. Op. Cit. p. 82.

77 Pesquisa do Instituto Locomotiva disponível em <https://www.ilocomotiva.com.br/singlepost/2019/04/17/EXAME-A-Economia-dos-Apps>. Acesso em 3.nov.19.
} 
A mudança na base técnica do capitalismo, com a tecnologia e as novas comunicações, reestruturou o mercado e deu azo ao consumo colaborativo. Para Gerald Davis ${ }^{78}$, professor de sociologia da Universidade de Michigan, nos Estados Unidos, trata-se de um "capitalismo de plataforma".

Nesse cenário, as tradicionais corporações empresariais deram lugar às empresas de páginas eletrônicas (web page enterprises), de menor materialidade, porque comumente desprovidas de espaço físico, e maior visibilidade. A novidade reside na possibilidade de a mão-de-obra humana ser requisitada pela Internet para um serviço em tempo real, algo até então restrito aos demais fatores de produção do capital e matéria-prima.

O cenário econômico deficiente em nosso país se mostrou bom hospedeiro ao capitalismo de plataforma. Foram mais de 2 milhões de empregos formais perdidos no Brasil de 2015 a $2017^{79}$. Um total de 12,6 milhões de desempregados, em 2019, com uma população ocupada em grande parte subutilizada e registrada na informalidade. São 38,8 milhões de brasileiros que trabalham por conta própria e sem carteira assinada ${ }^{80}$.

O elevado desemprego faz, por um lado, consumidores procurarem por serviços mais baratos e, por outro, trabalhadores procurarem por novas formas de emprego. Ainda, a ascensão econômica das classes C, D e E, que passaram a consumir pela internet, e a diminuição dos preços de planos de internet pelas operadoras, permitiram às plataformas digitais se tornarem uma rápida solução para a crise.

\footnotetext{
${ }^{78}$ DAVIS, G. F. What might replace the modern corporation? Uberization and the web page enterprise. Seattle University Law Review, 39, p. 501-515, 2016. Disponível em: $<$ https://digitalcommons.law.seattleu.edu/sulr/vol39/iss2/13/>. Acesso em: 24.out.18.

${ }^{79}$ ALVARENGA, Darlan. Brasil só deve recuperar estoque de empregos perdidos a partir de 2021. G1. Disponível em <http://g1.globo.com/economia/concursos-e-emprego/noticia/2016/08/brasilso-deve-recuperar-estoque-de-empregos-perdidos-partir-de-2021.html>. Acesso em 13.nov.18.

${ }^{80}$ SILVEIRA, Daniel. Desemprego fica em 11,8\% em agosto e atinge 12,6 milhões, diz IBGE. G1. Disponível em < https://g1.globo.com/economia/noticia/2019/09/27/desemprego-fica-em118percent-em-agosto-diz-ibge.ghtml>. Acesso em 3.nov.19.
} 
A tecnologia extinguiu a realidade fática do emprego nos moldes industriais tradicionais (um trabalho típico, de prazo indeterminado e performado em local fixo) e possibilitou a dispersão do trabalho. No entanto, não resultou em igual democratização de seu processo ou em menor controle. Ao contrário, permitiu a centralização do capital, a intensificação do trabalho, a extensão do tempo de trabalho e a transferência dos riscos e custos da atividade para os trabalhadores.

Se por um lado é notada a abertura de novos postos de trabalho, a melhoria da produtividade e a otimização dos serviços; por outro, agravamse os problemas de ordem social, especialmente, em razão da flexibilização do trabalho ${ }^{81}$.

O cerne da flexibilização, compreendida por Ludmila Costhek Abílio, pós-doutora em Ciências Sociais pela Universidade de São Paulo, como a eliminação de direitos sociais associados ao trabalho, está no "movimento que transfere para o trabalhador a administração de seu trabalho, dos custos e dos riscos, sem com isso perder o controle sobre sua produção." 82

O Procurador do Trabalho Renan Bernadi Kalil, também pesquisador da Universidade de São Paulo, identificou que 53\% dos motoristas da Uber na capital paulista trabalham mais de 10 horas por dia e $68 \%$ dirigem mais de cinco dias na semana para conseguir renda para pagar suas despesas imediatas $^{83}$. Em razão de constatações como esta, o Banco Mundial propõe que a proteção social seja uma garantia independente da profissão.

\footnotetext{
${ }^{81}$ Trata-se do Relatório Mundial de Desenvolvimento 2019 - A natureza mutável do trabalho. Profissionais do futuro devem aprender empatia e julgamento crítico, defende Banco Mundial. ONUBR Nações Unidas no Brasil. Disponível em <https://nacoesunidas.org/profissionais-dofuturo-devem-aprender-empatia-e-julgamento-critico-defende-bancomundial/?fbclid=IwAR3z7QDqSPZMRj7QHDoiXSYnyiw_6OleHDQyryoHucjhvkXGxeeJtXsrVj w>. Acesso em 12.nov.18.

${ }^{82}$ ABÍLIO, Ludmila Costhek. Uberização do trabalho: subsunção real da viração. Disponível em <http://passapalavra.info/2017/02/110685/>. Acesso em 19. Out. 2018.

${ }^{83}$ PASSOS, Eduardo Neves Barbosa. Prestação de serviço via aplicativo carece de regulação específica. AUN - Agência Universitária de Notícias da USP. Disponível em < https://paineira.usp.br/aun/index.php/2019/05/28/prestacao-de-servico-via-aplicativo-carece-deregulacao-especifica/>. Acesso em 10.nov.19.
} 
Apesar de ser apenas uma dentre várias personagens na economia de compartilhamento, a empresa Uber foi eleita como referência ao modelo em virtude da sua notória presença de mercado, conforme exposto na seção anterior. Para mais, sua relevância levou os autores Gerald Davis e Steven Hill a cunharem as expressões "Uberização" e "Uber Economia", respectivamente. Esta, compreendida como uma economia baseada em trabalhos temporários e de meio período; aquela, como a possibilidade de trabalhos sob demanda serem contratados como tarefas através de plataformas online.

Ludmila Costhek Abílio sintetiza de forma pontual o potencial de precarização da "Uberização". Reconhece o fenômeno como:

“(...) um novo estágio da exploração do trabalho, que traz mudanças qualitativas ao estatuto do trabalhador, à configuração das empresas, assim como às formas de controle, gerenciamento e expropriação do trabalho. (...) consolida a passagem do estatuto de trabalhador para o de um nanoempresário-de-si permanentemente disponível ao trabalho; retira-lhe garantias mínimas [não se trata apenas da eliminação do vínculo de emprego] ao mesmo tempo que mantém sua subordinação." 84

Nessas circunstâncias, a dispensabilidade do emprego formal, com a redução das garantias de proteção social, e a frequente ocultação de um negócio materialmente capitalista sob a forma de compartilhamento, com a transferência dos riscos da atividade laboral para o trabalhador, são os maiores riscos à qualidade das relações laborais.

Segundo Gerald Davis ${ }^{85}$, um dos motivos da formalização do vínculo empregatício é a necessidade de a empresa ter à sua disposição um contingente de trabalhadores aptos a satisfazer demandas que nem sempre são previsíveis e que requerem distintas capacidades laborais. Assim, as plataformas digitais tornam a formalização da relação de emprego

\footnotetext{
${ }^{84}$ ABÍLIO, Ludmila Costhek. op. cit.

${ }^{85}$ DAVIS, G. F. op. cit., p. 512.
} 
desnecessária ao permitirem a requisição de mão-de-obra, em tempo real, para satisfazer uma demanda imprevisível e temporária.

Ocorre, então, a substituição do tradicional emprego formal, com as suas correspondentes garantias ao empregado, pela contratação por tarefa para a execução de um serviço específico. É um trabalho de perfil instável e transitório, sem estatuto profissional específico e, em geral, exercido como mero complemento de renda (um "bico") por um "trabalhador amador produtivo". É uma "cultura de viração", como nota Ludmila Costhek Abílio ${ }^{86}$.

Preocupa, ainda, a comum dissimulação do caráter colaborativo por empresas que praticam negócios tradicionais. São empresas que se propagandeiam como plataformas mediadoras das demandas dos consumidores e ofertas dos prestadores, sem burocracias e hierarquias, mas que, pela sua infraestrutura virtual própria, ditam as regras do negócio. No fundo e na prática, transferem os riscos da atividade para os trabalhadores autônomos disponíveis ao trabalho.

Na relação uberizada, o trabalhador, doravante "parceiro", permanece, tal qual na relação tradicional de emprego, em relação desigual de poder com a empresa para definir seus ganhos, a intensidade do seu trabalho, a extensão da sua jornada. Muda a forma de controle, o gerenciamento, a vigilância e a expropriação do seu trabalho. Segundo Ludmila Costhek Abílio: "ao mesmo tempo evidentes e pouco tangíveis." 87

${ }^{86}$ ABÍLIO, Ludmila Costhek. op. cit.

${ }^{87}$ ABÍlLIO, Ludmila Costhek. op. cit. 


\section{CAPÍTULO III - ASPECTOS JURÍDICOS DO TRABALHO DO MOTORISTA DA UBER}

Até o momento foram estudados os pressupostos da relação empregatícia à luz da doutrina, após os quais se expôs a realidade fática do trabalho moderno por meio de artigos. Agora, serão analisadas decisões judiciais paradigmáticas acerca da regulação jurídica cabível ao motorista vinculado à plataforma Uber. Perceber-se-á, tal qual Gerald Davis reconhece em seu trabalho, que nossas categorizações não são capazes de apreender o mundo na dimensão em que ele se apresenta hoje.

\subsection{Casos paradigmáticos da Uber nos Tribunais Internacionais}

A regulamentação do serviço oferecido pela Uber e a natureza do trabalho de seus motoristas não são problemas exclusivos do Judiciário brasileiro. O serviço das plataformas eletrônicas como um todo, enquanto negócios disruptivos que adentram mercados tradicionais, invariavelmente suscita conflitos. Por isso, ao se analisar as controvérsias de uma plataforma de nível global como a Uber, torna-se relevante a exposição das experiências jurisdicionais internacionais e pátria. Para além, o próprio art. $8^{\circ}$ da CLT $^{88}$ prevê o direito comparado como fonte subsidiária.

Só nos Estados Unidos, país de origem da Uber, os serviços da empresa já foram suspensos ou limitados nos Estados da Virginia, Maryland, South Carolina, New York City, Nevada, Miami, Philadelphia, Chicago, Birmingham, New Orleans e San Antonio $^{89}$. Inúmeras reclamações trabalhistas pelo reconhecimento do vínculo empregatício tramitam nos

\footnotetext{
${ }^{88}$ Art. $8^{\circ}$, CLT - As autoridades administrativas e a Justiça do Trabalho, na falta de disposições legais ou contratuais, decidirão, conforme o caso, pela jurisprudência, por analogia, por eqüidade e outros princípios e normas gerais de direito, principalmente do direito do trabalho, e, ainda, de acordo com os usos e costumes, o direito comparado, mas sempre de maneira que nenhum interesse de classe ou particular prevaleça sobre o interesse público.

${ }^{89}$ KRAMER, Josiane Caldas. op. cit., p. 97.
} 
tribunais norte-americanos e levam a companhia à acordos extrajudiciais como forma de evitar condenações milionárias nos tribunais. Em um deles, em 2016, que afeta duas ações coletivas com mais de 385 mil motoristas da Califórnia e Massachusetts, a Uber pagou uma indenização de 308 milhões de reais para manter os trabalhadores classificados como autônomos ${ }^{90}$.

Em setembro de 2019, o Estado da Califórnia, nos Estados Unidos, sancionou uma lei, a Assembly Bill 5 (AB 5), que positiva, no Código de Trabalho do Estado, recente decisão da Suprema Corte da Califórnia no caso Dynamex.

Na lide em questão, de abril de 2018, a Corte californiana instituiu a presunção do emprego em qualquer prestação de serviço remunerada e definiu um procedimento para a verificação da sua inexistência: o "Teste ABC". Três requisitos devem ser cumulativamente demonstrados para que o teste comprove a ausência da relação de emprego e ateste o status de prestador de serviço independente:

(A) que o trabalhador é livre, no contrato e de fato, do controle e direção do tomador na execução do trabalho;

(B) que o trabalhador executa trabalho fora do curso normal de negócios do contratante; $\mathrm{e}$

(C) que o trabalhador, independente da natureza do serviço prestado, atua habitualmente em atividade comercial, ocupação ou negócio estabelecido.

Assim, a AB 5 regulamenta a classificação jurídica dos empregados falsamente tidos como autônomos - prática comum de empresas tradicionalmente capitalistas que se camuflam na economia de compartilhamento, como visto.

\footnotetext{
${ }^{90}$ MOYA, Ramón. Dois motoristas britânicos processam Uber para ter direitos trabalhistas. Disponível em < https://brasil.elpais.com/brasil/2016/07/19/economia/1468929161_021578.html>. Acesso em 5.nov.19.
} 
Rodrigo Carelli, Procurador do MPT, tece comparações pertinentes entre a norma aprovada na Califórnia e o ordenamento trabalhista pátrio ${ }^{91}$. Carelli nota que, enquanto na Califórnia o vínculo empregatício é presumido, aplicando-se o Teste ABC com o fim de demonstrar sua inexistência; no Brasil, os pressupostos fáticos-jurídicos do emprego, consagrados nos artigos $2^{\circ}$ e $3^{\circ}$ da CLT, e já estudados neste trabalho, devem ser demonstrados para que se comprove o vínculo empregatício.

Outra distinção entre os ordenamentos é que o requisito $\mathrm{C}$ do Teste $\mathrm{ABC}$, ao exigir que o autônomo já esteja estabelecido em alguma atividade econômica, colide com a frequente prática brasileira de condicionar o emprego à abertura de uma empresa (pessoa jurídica ou MEI). Hoje, no Brasil, os motoristas de aplicativos de mobilidade urbana que desejam gozar de benefícios previdenciários devem se formalizar como microempreendedores individuais $(\mathrm{MEI})^{92}$.

Já o requisito A do Teste $\mathrm{ABC}$ se aproxima do nosso ordenamento tanto na sua literalidade como na sua principiologia. Trata de "controle e direção", não de subordinação, assim como a CLT. Ademais, prevê que a liberdade de execução do trabalho ocorra nos planos formal e fático, tal qual o princípio da primazia da realidade albergado no art. $9^{\circ}$ da CLT ${ }^{93}$.

Por fim, quanto ao requisito B do Teste, sua interpretação inicial foi pelo critério da atividade-fim, o que levou a Uber a imediatamente anunciar que seu negócio principal se trata da plataforma de tecnologia em si - e não o transporte e, portanto, os motoristas não integram sua atividade principal.

\footnotetext{
${ }^{91}$ CARELLI, Rodrigo. A lei californiana é um trem bala na contramão da reforma trabalhista brasileira: muito mais do que considerar empregados os trabalhadores de aplicativos - artigo. Disponível em <https://rodrigocarelli.org/2019/10/01/a-lei-californiana-e-um-trem-bala-nacontramao-da-reforma-trabalhista-brasileira-muito-mais-do-que-considerar-empregados-ostrabalhadores-de-aplicativos-artigo/>. Acesso em 4.nov.19.

${ }^{92}$ FONSECA, Mariana. Motoristas de 99, Cabify e Uber agora podem se registrar como MEIs. Disponível em <https://exame.abril.com.br/pme/motoristas-de-99-cabify-e-uber-agora-podem-seregistrar-como-mei/>. Acesso em 4.nov.11.

${ }^{93} \mathrm{CLT}$, Art. $9^{\circ}$ - Serão nulos de pleno direito os atos praticados com o objetivo de desvirtuar, impedir ou fraudar a aplicação dos preceitos contidos na presente Consolidação.
} 
Contudo, Carelli propõe que sua leitura seja pela dimensão estrutural da subordinação ou pela teoria dos fins da empresa. Dessa forma, a mera inserção do trabalhador na dinâmica empresarial ou nos fins do empreendimento acarretaria controle sobre o trabalho e impossibilitaria o trabalho autônomo.

$\mathrm{Na}$ Europa, dois casos paradigmáticos também merecem consideração. Um litígio espanhol, em razão do entendimento do Tribunal de Justiça da União Europeia (TJUE) quanto à natureza do serviço ofertado pela Uber; e um londrino, especialmente pelos critérios adotados pelo Tribunal do Trabalho local para o reconhecimento do vínculo empregatício entre a Uber e seus motoristas.

Em 2017, uma associação profissional de taxistas em Barcelona, na Espanha, a Elite Taxi, ajuizou reclamatória face à Uber por concorrência desleal e prática enganosa sob a argumentação de que à Uber e seus motoristas não eram requeridas licenças e autorizações administrativas para atuarem, tal qual requerido ao serviço de táxi de Barcelona.

A fim de qualificar as práticas da Uber como desleais ou não, o TJUE entendeu pertinente, antes, averiguar se haveria a necessidade de a empresa operar com as referidas licenças. Prejudicialmente, portanto, coube-lhe analisar qual a natureza do serviço da Uber.

O Tribunal descreve o serviço da Uber como ${ }^{94}$ :

"Um serviço de intermediação que permite a transmissão, através de uma aplicação
para telefone inteligente, de informações relativas à reserva do serviço de
transporte entre o passageiro e o motorista não profissional que utiliza o seu próprio
veículo, que efetuará o transporte."

Para o TJUE, este serviço não se limita ao mero transporte porque não se restringe a deslocar fisicamente pessoas ou bens de um ponto A até um

\footnotetext{
${ }^{94}$ LUXEMBURGO. Tribunal de Justiça da União Europeia (TJUE). Processo C-434/15. Autor: Asociación Profesional Elite Taxi. Réu: Uber Systems Spain. Juiz Rel. D. Šváby. DJe: 20/12/17.
} 
ponto B através de um veículo. Tampouco limita-se à intermediação, pois não estabelece uma simples ligação, através de uma plataforma eletrônica, entre um motorista não profissional, dotado do seu próprio automóvel, e uma pessoa que deseja se deslocar no perímetro urbano.

Ainda que aproxime de um serviço de sociedade de informação porque prestado mediante remuneração, à distância, por via eletrônica e mediante pedido individual de um destinatário de serviços, também não se restringe à esta categorização. A Uber vai além: cria uma oferta de serviço de transporte, disponibilizada e controlada pela plataforma eletrônica da empresa.

Não fosse a Uber, a ligação entre passageiros e motoristas não existiria na plataforma virtual, mas ainda assim as pessoas se deslocariam. A oferta na plataforma é criada pela Uber. Ademais, a condição de prestação do serviço é manifestamente influenciada pela empresa, que controla o preço das corridas, cobra o preço do cliente antes de entregar a parte ao motorista, controla a qualidade dos carros e dos motoristas, inclusive, podendo excluílos da plataforma.

O TJUE foi capaz de apreender a realidade fática para além da limitação das categorias até então apresentadas. Reconheceu a natureza do negócio da Uber como um serviço de intermediação que integra um sistema global de transporte. Por conseguinte, trata-se de um negócio que integra a categoria dos serviços de transporte, que inclui qualquer ato físico de deslocamento de pessoas ou mercadorias de um local para outro através de um meio de transporte.

Essa decisão do TJUE desconstruiu a tese sustentada pela Uber, e impressa nos termos de seu contrato de serviços, de que a Uber atua como mero agente de intermediação entre o provedor do transporte e o passageiro. Nota-se que é uma linha de argumentação favorável à empresa porque a isenta, na maior parte dos locais nos quais atua, das burocracias impostas ao 
setor de transporte, bem como inviabiliza que os motoristas vinculados à plataforma sejam considerados inseridos em sua atividade-fim (o que impede, ou ao menos dificulta, o reconhecimento do vínculo de empregatício).

O segundo caso paradigmático data de 2015. Foi uma ação coletiva ajuizada no Tribunal do Trabalho do Reino Unido, por James Farrar e Yaseen Aslam, ambos motoristas da Uber em Londres, reclamando o pagamento de salário mínimo e descanso remunerado em virtude de suas qualificações como empregados da empresa.

Na ocasião, a Uber apresentou suas tradicionais contrarrazões de que a relação jurídica entre a plataforma e o motorista à ela vinculado é uma de agenciamento, de natureza cível, regulada por acordo escrito que expressamente define a Uber como agente do motorista (que é quem presta o serviço de transporte ao passageiro).

Ao examinar o contexto fático-probatório, o Tribunal britânico constatou uma discrepância no poder de barganha entre as partes e privilegiou, tal como o TJUE no prévio caso espanhol, a primazia da realidade em detrimento da análise contratual. Na visão do Tribunal, os termos contratuais da empresa não correspondem aos seus relacionamentos e obrigações reais. Consistem em ficções, linguagem distorcida e terminologias inventadas com as quais motoristas e passageiros são compelidos a anuir.

Dessa forma, concluiu que o âmago dos serviços da Uber reside no deslocamento de pessoas. A plataforma oferece uma variedade de transportes que jamais poderiam ser oferecidos, individualmente, por cada um dos seus motoristas. Por isso, pode-se dizer, assim como concluiu o TJUE, que a Uber cria uma demanda de transporte, mais do que simplesmente agencia motoristas. Ocorre que a estrutura através da qual a empresa oferece o seu 
produto de transporte é engenhosamente arquitetada para que se isente das responsabilidades e burocracias comumente imputadas ao setor.

Nesse cenário, o Tribunal entendeu que os motoristas estão incorporados no negócio de transporte da Uber, pois sujeitos a arranjos e controles da empresa aos quais não se submeteriam caso trabalhassem autonomamente, em um relacionamento contratual direto com o passageiro. Conforme nota o acórdão, "the notion that Uber in London is a mosaic of 30,000 small businesses linked by a common 'platform' is to our minds faintly ridiculous." 95

Ademais, Josiane Caldas Kramer lista em sua dissertação fatos que o Tribunal considerou determinantes na configuração do vínculo com a $\operatorname{Uber}^{96}$ : entrevistar e recrutar os motoristas; manter acesso pessoal e intransferível ao motorista cadastrado no aplicativo da plataforma; controlar as informações essenciais dos passageiros (identificação, contato e destinação pretendida), excluindo-as do conhecimento do motorista; exigir que motoristas aceitem e/ou não cancelem viagens; determinar a rota padrão da corrida; fixar a tarifa e impedir o motorista de negociar um valor maior com o passageiro; impor inúmeras condições aos motoristas (como escolha limitada de veículos aceitáveis); controlar os motoristas por um sistema de rating, sob parâmetros que ensejam procedimentos gerenciais e disciplinares; e ter o direito de alterar os termos contratuais de forma unilateral.

Consoante apontado no acórdão:

"93. ... we are clear that they provide their work 'for' Uber. We are equally clear that they do so pursuant to a contractual relationship. If, as we have found, there is no contract with the passenger, the finding of a contractual link with Uber is inevitable. But we do not need to base our reasoning on a process of elimination. We are entirely satisfied that the drivers are recruited and retained by Uber to enable it to operate its transportation business. The essential bargain between driver

\footnotetext{
95 "A ideia de que a Uber em Londres seria um mosaico de 30,000 pequenos negócios ligados por uma plataforma em comum é, em nossa mente, ridícula". (tradução nossa). REINO UNIDO. UK Employment Tribunal. Caso 2202551/2015. Autor: Mr. Y Aslam, Mr J Farrar e o. Réu: Uber B.V., Uber London, Uber Britannia. Juiz A. M. Snelson. DJe: 28/10/16. p 20.

${ }^{96}$ KRAMER, Josiane Caldas. op. cit., p. 99.
} 
and organisation is that, for reward, the driver makes himself available to, and does, carry Uber passengers to their destinations. Just as in Autoclenz, the employer is precluded from relying upon its carefully crafted documentation because, we find, it bears no relation to reality. And if there is a contract with Uber, it is self-evidently not a contract under which Uber is a client or customer of a business carried on by the driver. ... we regard that notion as absurd." 997

"94.... the agreement between the parties is to be located in the field of dependent work relationships; it is not a contract at arm's length between two independent business undertakings. Moreover the drivers do not market themselves to the world in general; rather they are recruited by Uber to work as integral components of its organisation." ${ }^{98}$

Por fim, o Tribunal definiu três parâmetros para que um motorista vinculado à plataforma fosse considerado empregado. Primeiro, o aplicativo da empresa deve estar ligado. Afinal, esta não é uma obrigação do motorista vinculado à plataforma; mas, uma vez que o faça, torna-se obrigatório que fique disponível. Em segundo lugar, o motorista deve atuar dentro do território para o qual possui autorização. E, por último, deve estar disponível e disposto a aceitar "corridas", independente de efetivamente carregar algum passageiro. Como nota o Tribunal, o serviço desejado pelo passageiro não se confunde com o requerido pela Uber. Isto, pois para que o negócio da Uber funcione é essencial que haja uma reserva de motoristas disponíveis.

\footnotetext{
97 "Estamos certos de que os motoristas providenciam seu trabalho para a Uber. Estamos igualmente certos de que o fazem em razão de um relacionamento contratual. Caso, conforme achamos, não há contrato do motorista com o passageiro, é inevitável que haja um do motorista com a Uber. Mas não precisamos basear nosso raciocínio em um processo de eliminação. Estamos satisfeitos de que os motoristas são recrutados e retidos pela Uber para permitir sua operação no negócio de transportes. A barganha entre o condutor e a empresa é de que, como recompensa, o motorista se faz disponível e carrega os passageiros da Uber para os seus destinos. Assim como no caso Autoclenz, o empregador não pode se amparar em suas documentações bem redigidas porque, como percebemos, elas não refletem a realidade. E se houver um contrato com a Uber, é evidente que não se trata de um no qual a Uber é cliente ou consumidora de um negócio do motorista... vemos esta noção como absurda." (Tradução nossa). REINO UNIDO. UK Employment Tribunal. Caso 2202551/2015. Autor: Mr. Y Aslam, Mr J Farrar e o. Réu: Uber B.V., Uber London, Uber Britannia. Juiz A. M. Snelson. DJe: 28/10/16. p. 22.

98 "O acordo entre as partes [motorista e Uber] deve ser localizado no campo dos relacionamentos de trabalho com dependência; não se trata de um contrato em que ambos negociantes agem de forma independente e sem influência um do outro. Ademais, os motoristas não se vendem para o público em geral, são recrutados pela Uber para trabalhar como componentes integrais da sua organização." (Tradução nossa). REINO UNIDO. UK Employment Tribunal. Caso 2202551/2015. Autor: Mr. Y Aslam, Mr J Farrar e o. Réu: Uber B.V., Uber London, Uber Britannia. Juiz A. M. Snelson. DJe: 28/10/16. p. 22.
} 
A partir da exposição desses casos paradigmáticos de distintas jurisdições constata-se a possibilidade da relação de trabalho dos motoristas vinculados à Uber ser uma de emprego. O vínculo, como aponta a jurisprudência comparada, não se configuraria pela mera subscrição do condutor na plataforma, mas pela sua atuação nesta em preenchimento aos requisitos configuradores da relação empregatícia (analisados em observação à primazia da realidade).

\subsection{Casos paradigmáticos da Uber nos Tribunais Brasileiros}

Não há lei específica no Brasil que regule a relação entre motoristas e empresas de mobilidade urbana. Cabe ao julgador, no caso concreto, o desafio de analisar os elementos fático-jurídicos dessa relação de trabalho anômala para enquadrá-la na categoria mais pertinente. Em janeiro de 2018, no país, tramitavam 55 ações envolvendo a Uber em casos de vínculo empregatício - com 53 decisões favoráveis à empresa (sendo 11 julgadas em $2^{\text {a }}$ instância $)^{99}$.

Foi em janeiro de 2017 que, pela primeira vez, a Justiça do Trabalho decidiu sobre a relação de emprego entre o motorista vinculado à Uber e a empresa ${ }^{100}$. A decisão foi proferida pela $37^{\text {a }}$ Vara do Trabalho de Belo Horizonte, que não reconheceu o vínculo de emprego entre o reclamante e a Uber, indeferindo as verbas trabalhistas postuladas.

Inicialmente, o reclamante relatou dispensa unilateral e abusiva, sem recebimento das devidas verbas trabalhistas; pagamento de salário-produção semanal de $\mathrm{R} \$ 504,42$; trabalho em sobrejornada durante todo contrato de trabalho; e labor em período noturno e em feriados sem os respectivos

99 MARTINES, Fernando. Em primeira decisão sobre o tema, TRT-2 nega vínculo de motorista com a Uber. Disponível em <https://www.conjur.com.br/2018-jan-06/decisao-tema-trt-negavinculo-motorista-uber>. Acesso em 11.nov.19.

${ }^{100}$ Processo no $^{\circ}$ 0011863-62.2016.5.03.0137 
adicionais e compensações. Pugnou pelo deferimento das multas dos arts. 467 e $477, \S 8^{\circ}$, da CLT; horas extraordinárias; adicional noturno e horas extras; remuneração dos domingos e feriados trabalhados; férias proporcionais acrescidas do terço; indenização por danos morais por ausência de sanitários e local para refeições; aviso prévio indenizado; $13^{\circ}$ salário proporcional; depósitos do FGTS acrescidos da multa rescisória de 40\%; e auxílio alimentação e cesta básica, de acordo com a norma coletiva de trabalho da categoria.

Em defesa escrita, a Uber arguiu preliminares de incompetência absoluta da justiça do trabalho e inépcia da petição inicial, bem como requereu a tramitação do feito em segredo de justiça. No mérito, arguiu inexistência do vínculo empregatício por ausência de pessoalidade, onerosidade, habitualidade e subordinação.

Sustentou a ausência de pessoalidade no fato de que o atendimento ao usuário seria possível por qualquer motorista parceiro disponível na plataforma. A falta de onerosidade, em virtude de a Uber ser a remunerada pelo reclamante para a utilização do aplicativo. A ausência de habitualidade, em virtude da falta de obrigatoriedade de dias e horários para a execução das atividades. E a inexistência de subordinação, na não exigência de exclusividade para a prestação do serviço.

Ainda, aduziu ser um serviço de intermediação via plataforma tecnológica. Afirmou que não presta serviço de transporte, nem opera como agente para o transporte de passageiro. É o reclamante quem contrata a Uber para uma "prestação de serviço de captação e angariação de clientes.":öbj]. ${ }^{101}$

101 BRASIL. TRIBUNAL REGIONAL DO TRABALHO DA $3^{\mathrm{a}}$ REGIÃO, 33 ${ }^{\mathrm{a}}$ VARA DO TRABALHO DE BELO HORIZONTE. Reclamação Trabalhista nº. 0011359-34.2016.5.03.0112. Juiz Márcio Toledo Gonçalves. Belo Horizonte, Decisão 13/02/17, DJe. 14/02/17. p. 9. Disponível em: 〈https://www.conjur.com.br/dl/juiz-reconhece-vinculo-emprego-uber.pdf >. Acesso em: 19. Out. 2018. 
A sentença firmou o entendimento de que a relação laboral em tela apresenta obrigações contratuais inerentes a qualquer contrato, mas não ostenta subordinação jurídica - motivo pelo qual incabível o vínculo empregatício. Compreendeu que a reclamada não impunha ordens ao reclamante sobre como ele deveria performar seus serviços, tratavam-se de meras recomendações. Assim, não haviam deveres jurídicos que o empregado devesse acatar partindo do empregador.

Outrossim, a aplicação da avaliação de performance do motorista feita pelos usuários como instrumento para sua permanência na plataforma também não caracterizaria subordinação. Seria apenas um risco assumido por ambos contratantes, já que a reclamada não teria ingerência sobre a sua análise.

Um mês depois, em fevereiro, a $33^{\mathrm{a}}$ Vara do Trabalho de Belo Horizonte reconheceu o liame empregatício entre um motorista e a Uber, em demanda semelhante à relatada. Condenou a empresa ao pagamento de aviso prévio indenizado, férias, $13^{\circ}$ salário, FGTS, adicionais de horas extra e noturno, e remuneração em dobro por feriados laborados ${ }^{102}$.

Na ocasião, a sentença contextualizou a controvérsia na dinâmica dos sistemas produtivos contemporâneos, aludindo ao fenômeno da "uberização" como um novo e emergente padrão de organização do trabalho fruto dos avanços tecnológicos, sucessor dos modelos fordista e toyotista, com potencial de se generalizar em todos os setores da economia e "firmado na tentativa de autonomização dos contratos de trabalho e na utilização de

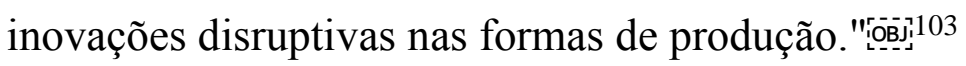

\footnotetext{
${ }^{102}$ Processo n $^{\circ}$ 0011359-34.2016.5.03.0112

103 BRASIL. TRIBUNAL REGIONAL DO TRABALHO DA $3^{\mathrm{a}}$ REGIÃO, 33 $3^{\mathrm{a}}$ VARA DO TRABALHO DE BELO HORIZONTE. Reclamação Trabalhista n ${ }^{\circ}$. 0011359-34.2016.5.03.0112. Juiz Márcio Toledo Gonçalves. Belo Horizonte, Decisão 13/02/17, DJe. 14/02/17. p. 10. Disponível em: <https://www.conjur.com.br/dl/juiz-reconhece-vinculo-emprego-uber.pdf>. Acesso em: 19. Out. 2018.
} 
$\mathrm{Na}$ análise do contexto fático-probatório, com especial valoração à prova oral, o Juízo considerou presentes os pressupostos da relação de emprego. O caráter intuitu personae da relação estaria refletido na exigência da Uber, ao pretenso motorista, de um cadastro virtual à título de seleção dos integrantes de seus quadros; bem como, no impedimento de que outra pessoa, que não a cadastrada, realize viagens no seu respetivo veículo cadastrado. Segundo o Juiz Márcio Toledo Gonçalves:

"Não se pode confundir a pessoalidade marcante da relação motorista-Uber com a
impessoalidade da relação usuário-motorista. Assim, da mesma forma que, na
maioria das vezes, não podemos escolher qual cozinheiro irá preparar nosso prato
em um restaurante ou qual vendedor irá nos atender em uma loja de sapatos, não é
dado ao usuário do aplicativo indicar qual motorista o transportará." 104

Quanto ao pressuposto da onerosidade, se entenderam presentes tanto seu aspecto objetivo como o subjetivo. Notou-se que a política de pagamento do serviço prestado era exclusivamente controlada pela reclamante, que remunerava e oferecia prêmios aos motoristas quando alcançadas condições pré-estabelecidas. Outrossim, os demonstrativos de pagamento ao motorista pelos serviços prestados aos usuários constavam do nome da ré, que retirava um percentual de $25 \%$ e repassava o restante ao condutor apenas no final de cada semana.

No exame da habitualidade, o Juízo adotou a teoria dos fins do empreendimento combinada com a teoria da eventualidade. $\mathrm{O}$ trabalhador eventual, portanto, seria aquele admitido para suprir uma demanda específica do negócio, com a duração do serviço condicionada ao motivo da contratação. E o não eventual, o que opera nos fins regulares da empresa. Dessa forma, enquadrou o motorista da Uber com um trabalhador não eventual porque atende à demanda intermitente da ré pelos serviços de transporte.

No que tange à subordinação, foi observada sua presença nas perspectivas objetiva e estrutural. $\mathrm{O}$ reclamante, inserido na dinâmica e 
organização do empreendimento, realizava os objetivos sociais da empresa, "oferecia prestação laboral indispensável aos fins da atividade empresarial, não possuindo uma organização própria e não percebendo verdadeiramente os frutos do seu trabalho". ${ }^{105}$ Tratava-se de uma alienação do trabalho em si, não do resultado deste.

Para além, se apurou que a reclamada controlava a forma de execução do serviço do reclamante, com possibilidade de sanções disciplinares tais quais bloqueios por recusas sucessivas de corridas ou por avaliações medianas de usuários. Ocorre que o controle seria difuso, "algorítmico" e "panóptico", feito pelas avaliações dos usuários na forma de notas e reclamações - realidade já abarcada pelo art. $6^{\circ}$, parágrafo único, $\mathrm{CLT}^{106}$, que consagra a subordinação clássica ao monitoramento eletrônico.

Em sede de RO, contudo, a $9^{\mathrm{a}}$ Turma do TRT da $3^{\mathrm{a}}$ Região reformou a sentença retro e declarou a inexistência da relação de emprego, determinando o afastamento da anotação da CTPS do autor pela reclamada, bem como a exclusão do pagamento das verbas trabalhistas. Para a Desembargadora Maria Stela Álvares da Silva, a contextualização da demanda individual na seara da "uberização" erroneamente lhe conferiu uma análise em perspectiva meta individual.

A Turma concluiu que o cadastro na plataforma não seria indicador de relação personalíssima, pois é permitido que, para o mesmo veículo, seja cadastrado um segundo motorista auxiliar - ou até mesmo que seja cadastrada pessoa jurídica detentora de frota de veículos.

\footnotetext{
105 Ibid. p. 27

${ }^{106}$ Art. $6^{\circ}$, CLT - Não se distingue entre o trabalho realizado no estabelecimento do empregador, o executado no domicílio do empregado e o realizado a distância, desde que estejam caracterizados os pressupostos da relação de emprego.

Parágrafo único. Os meios telemáticos e informatizados de comando, controle e supervisão se equiparam, para fins de subordinação jurídica, aos meios pessoais e diretos de comando, controle e supervisão do trabalho alheio. (grifo nosso).
} 
No mais, dissentiu do entendimento sobre a natureza do serviço prestado pela Uber, compreendendo-o como um de intermediação entre consumidores e fornecedores. Dessa forma, tampouco concordou com a aplicação de subordinação estrutural ao caso. Não reconheceu aspectos de controle da Uber na prestação do serviço pelo motorista. Entendeu que este teria independência e autonomia para recusar passageiros, ligar ou desligar o aplicativo, e definir seu horário de trabalho. Também, que gerenciava o próprio trabalho ao arcar, por exemplo, com os custos do veículo, de seguro e de danos causados por passageiros.

A exposição dessas decisões do TRT-3 é especialmente importante por serem as pioneiras sobre o tema no nosso Judiciário. Feitas de forma minuciosa, permitem que sejam compreendidos os argumentos padrões empregados pelos reclamantes e reclamados, a despeito de pequenas especificidades de cada caso concreto.

Nota-se que a divergência acerca do tema atinge Varas e Turmas de Tribunais de uma mesma região. Tal como na $3^{\text {a }}$ Região, em São Paulo, TRT da $2^{\text {a }}$ Região, apesar de a primeira decisão em segunda instância sobre o tema, em janeiro de 2018, proferida pela $8^{\mathrm{a}}$ Turma do Tribunal, ter favorecido à Uber $^{107}$, recente decisão da $15^{\text {a }}$ Turma, de agosto de 2018, reconheceu o liame empregatício $^{108}$.

Nelson Mannrich tece consideração oportuna de ser comentada sobre como o debate no Direito do Trabalho tende à bipolaridade ${ }^{109}$. Observa que, em geral, ou os interesses do empregado são considerados acima de tudo, ou serve-se cegamente à empresa. Assim, mais do que tentar enquadrar os

\footnotetext{
${ }^{107}$ Recurso Ordinário n ${ }^{\circ}$ 1001574-25.2016.5.02.0026

108 Recurso Ordinário no $1000123-89.2017 .5 .02 .0038$

109 MANNRICH, Nelson. Direito do trabalho em tempos de crise: qual a medida da reforma?. Revista eletrônica [do] Tribunal Regional do Trabalho da $9^{a}$ Região, Curitiba, PR, v. 6, n. 58, p. 31 47, mar./abr. 2017. Disponível em <https://juslaboris.tst.jus.br/bitstream/handle/20.500.12178/105532/2017_mannrich_nelson_direit o_trabalho.pdf? sequence=1\&isAllowed=y>. Acesso em 13.nov.19.
} 
motoristas de plataformas digitais na CLT ou não, urge que se repense o Direito do Trabalho com razoabilidade.

Nesse sentido, o próprio autor propõe que seja feita uma releitura dos princípios clássicos do direito trabalhista para que não sejam um valor em si, mas que se justificassem na medida do trabalhador enquanto pessoa humana e digna; bem como uma retipificação do contrato individual de trabalho que supere o binômio do trabalho subordinado e autônomo ${ }^{110}$.

\footnotetext{
${ }^{110}$ Para Luis Carlos Amorim Robortella, “(...) o grande desafio atual está relacionado com a adoção de novas técnicas de proteção, que levem em conta as transformações no mundo do trabalho trazidas pelas novas tecnologias, pelo crescimento do desemprego, pela revalorização do trabalho autônomo, pela magnitude da economia subversa. " (Disponível em: <http://www.revistas.usp.br/rfdusp/article/download/67439/70049/>. Acesso em 30.out.18)
} 


\section{CONCLUSÃO}

Após o conteúdo analisado, constata-se que a base tradicional do capitalismo e, como resultado, a organização do trabalho, perpassam grandes transformações devido à tecnologia. Vantagens e desvantagens podem ser observadas na emergência do modelo econômico de compartilhamento, sendo especialmente preocupante a questão da qualidade dos trabalhos gerados - característica que tem sido estudada como um fenômeno em si: a "Uberização".

Nesse novo paradigma, o estudo específico da categoria dos motoristas vinculados à empresa Uber demonstra que um dos fatores a tornarem a qualidade do trabalho "uberizado" precária é a falta de uma proteção jurídica sólida, que resulta em insegurança jurídica para trabalhadores e empresários.

Isso, porque os contornos desse novo trabalho se afastam das nossas formulações jurídicas celetistas tradicionais, como notado no estudo dos pressupostos da relação de emprego previstos nos artigos $2^{\circ}$ e $3^{\circ}$ da CLT que permanecem essencialmente ligados à uma realidade fabril do "trabalho espacialmente concentrado, tecnicamente atomizado e hierarquicamente gerido, seguindo o modelo fordista-taylorista"111.

Ainda, essa incompatibilidade da realidade fática à prescrição normativa disponível se traduz em posições jurisprudenciais diametralmente opostas, conforme se observa nas sentenças analisadas das $33^{\mathrm{a}}$ e $37^{\mathrm{a}}$ Varas do Trabalho de Belo Horizonte e nos acórdãos das $8^{\mathrm{a}}$ e $15^{\mathrm{a}}$ Turmas do TRT da $2^{\mathrm{a}}$ Região.

111 FELICIANO, Guilherme Guimarães; PASQUALETO, Olívia de Quintana Figueiredo. (Re)descobrindo o Direito do Trabalho. JOTA. Disponível em < https://www.jota.info/paywall?redirect_to=//www.jota.info/opiniao-e-analise/colunas/juizo-devalor/redescobrindo-o-direito-do-trabalho-06052019>. Acesso em 10.nov.19. 
Ao fim do estudo feito não parece razoável que qualquer motorista vinculado à Uber, pelo mero fato de estar inscrito na plataforma, seja reconhecido como um empregado da empresa. Contudo, tampouco parece razoável que nenhum assim seja reconhecido, a depender da forma de execução do labor. Nesse sentido, os casos paradigmáticos internacionais expostos apresentam razoáveis soluções para a controvérsia, pois propõem critérios sólidos que permitem identificar o vínculo de emprego na execução do trabalho "uberizado".

$\mathrm{Na}$ falta de uma legislação que seja especificamente aplicável aos trabalhadores de plataformas móveis ou de uma jurisprudência pacífica sobre o tema, é preciso que, para além de um esforço improdutivo de subsunção, se repense a aplicação do Direito do Trabalho em si. Afinal, a ordem econômica, conforme estatui o art. 170 da CRFB/88, é fundada tanto na livre iniciativa quanto na valorização do trabalho humano.

Nas palavras de Vicente Paulo e Marcelo Alexandrino:

\begin{abstract}
"Essas disposições, que são as mais gerais acerca da ordem econômica, revelam nitidamente o caráter compromissário de nossa Carta Política. Em vez de assumir como um dado inelutável a consagrada cisão entre o "capital e trabalho", o histórico antagonismo entre "empresário e trabalhador", o texto constitucional procura transmitir uma ideia de integração, de harmonia, de sorte que assegura a livreiniciativa (portanto, a apropriação privada dos meios de produção, a liberdade de empresa), mas determina que o resultado dos empreendimentos privados deve ser a concretização da justiça social, o que exige, entre outras coisas, a valorização do trabalho humano. De todos os fatores de produção, portanto, o trabalho humano deve ser aquele colocado em primeiro lugar. O empreendedorismo é um valor consagrado, desde que valorize o trabalho humano e contribua para assegurar a todos uma existência digna."112
\end{abstract}

${ }^{112}$ PAULO, Vicente; ALEXANDRINO, Marcelo. Manual de direito do trabalho. $17^{\mathrm{a}}$.ed. Rio de Janeiro: Forense; São Paulo: Método, 2013, p.1022. 


\section{BIBLIOGRAFIA}

ABÍLIO, Ludmila Costhek. Uberização do trabalho: subsunção real da viração. Disponível em <http://passapalavra.info/2017/02/110685/>. Acesso em 19. Out. 2018.

ALT, Verônica Rossa. Análise Jurídica da Prestação de Trabalho do Motorista por Aplicativos de Transporte Urbano: O Caso Uber. Tese (Trabalho de Conclusão de Curso de Graduação) - Universidade Federal do Rio Grande do Sul, Faculdade de Direito, Curo de Ciências Jurídicas e Sociais. Porto Alegre, 2017.

BELTRAN, Ari Possidonio. Dilemas do trabalho e do emprego na atualidade. $1^{\text {a }}$ ed.. São Paulo: LTr, 2001. 264 p.

BRASIL. TRIBUNAL REGIONAL DO TRABALHO DA $2^{\mathrm{a}}$ REGIÃO, $48^{\mathrm{a}}$ VARA DO TRABALHO DE SÃO PAULO. Reclamação Trabalhista $n^{\circ}$. 1002011-63.2017.5.02.0048. Juíza Christina de Almeida Pedreida. São Paulo, Decisão 15/07/18, DJe. 23/07/18. Disponível em: <https://www.escavador.com/diarios/683433/TRT-2/J/2018-0723/339316335/movimentacao-do-processo-1002011-6320175020048>. Acesso em: 19.Out.2018.

BRASIL. TRIBUNAL REGIONAL DO TRABALHO DA $3^{\mathrm{a}}$ REGIÃO, $33^{\mathrm{a}}$ VARA DO TRABALHO DE BELO HORIZONTE. Reclamação Trabalhista n. 0011359-34.2016.5.03.0112. Juiz Márcio Toledo Gonçalves. Belo Horizonte, Decisão 13/02/17, DJe. 14/02/17. Disponível em: 
<https://www.conjur.com.br/dl/juiz-reconhece-vinculo-emprego-uber.pdf $>$. Acesso em: 19.Out.2018.

BRASIL. TRIBUNAL REGIONAL DO TRABALHO DA $3^{\mathrm{a}}$ REGIÃO, $37^{\mathrm{a}}$ VARA DO TRABALHO DE BELO HORIZONTE. Reclamação Trabalhista $\mathrm{n}^{\circ}$. 0011863-62.2016.5.03.0137. Juiz Filipe de Souza Sickert. Belo Horizonte, Decisão 30/01/17, DJe. 31/01/17. Disponível em: <https://www.conjur.com.br/dl/justica-trabalho-fixa-motorista-uber.pdf>. Acesso em: 11.nov.2019.

BRASIL. TRIBUNAL REGIONAL DO TRABALHO DA $3^{\mathrm{a}}$ REGIÃO, $9^{\mathrm{a}}$ TURMA. Recurso Ordinário $\mathrm{n}^{\circ}$. 0011359-34.2016.5.03.0112. Relatora Desembargadora Maria Stela Álvares da Silva Campos. Belo Horizonte, Decisão 23/05/17, DJe. 25/05/17. Disponível em: $<$ https://www.jota.info/wpcontent/uploads/2017/05/Aco\%CC\%81rda\%CC\%83o-RO-Uber-X-RodrigoLeonardo-Silva-Ferreira-proc.-0011359-34.2016.5.03.0112-2.pdf?x48657>. Acesso em: 19.out.2018.

CARELLI, Rodrigo. Trabalho no século XXI, a Justiça do Trabalho e as novas formas de trabalho por plataformas. Disponível em <https://rodrigocarelli.org/2018/08/10/trabalho-no-seculo-xxi-a-justica-dotrabalho-e-as-novas-formas-de-trabalho-por-plataformas/>. Acesso em 19. Out. 2018.

CARELLI, Rodrigo. A lei californiana é um trem bala na contramão da reforma trabalhista brasileira: muito mais do que considerar empregados os 
trabalhadores de aplicativos - artigo. Disponível em <https://rodrigocarelli.org/2019/10/01/a-lei-californiana-e-um-trem-bala-nacontramao-da-reforma-trabalhista-brasileira-muito-mais-do-que-considerarempregados-os-trabalhadores-de-aplicativos-artigo/>. Acesso em 4.nov.19.

CASSAR, Vólia Bomfim. Direito do Trabalho. $11^{\mathrm{a}}$ ed. Rio de Janeiro: Forense; São Paulo: MÉTODO, 2015.

COURA, Kalleo. TRT-3 nega vínculo de emprego de motorista com a Uber. Jota. Disponível em < https://www.jota.info/tributos-e-empresas/trabalho/trt3-nega-vinculo-de-trabalho-de-motorista-com-a-uber-25052017>. Acesso em 19. Out. 2018.

DAVIS, G. F. What might replace the modern corporation? Uberization and the web page enterprise. Seattle University Law Review, 39, p. 501-515, 2016.

$<$ https://digitalcommons.law.seattleu.edu/sulr/vol39/iss2/13/>. Acesso em: 24.out.18.

DELGADO, M. G. Curso de Direito do Trabalho. $16^{\mathrm{a}}$ ed.. São Paulo: LTr, 2017. 1669 p.

FELICIANO, Guilherme Guimarães; PASQUALETO, Olívia de Quintana Figueiredo. (Re)descobrindo o Direito do Trabalho. JOTA. Disponível em <https://www.jota.info/paywall?redirect_to=//www.jota.info/opiniao-eanalise/colunas/juizo-de-valor/redescobrindo-o-direito-do-trabalho06052019>. Acesso em 10.nov.19. 
GASPAR, Danilo Gonçalves. A Crise da subordinação jurídica clássica enquanto elemento definidor da relação de emprego e a proposta da subordinação potencial. Dissertação de Mestrado. Universidade Federal da Bahia, Faculdade de Direito. Salvador, 2011. p. 112-128.

HARARI, Yuval Noah. Sapiens - Uma breve história da humanidade. $28^{\mathrm{a}}$ Ed. Porto Alegre, RS: L\&PM, 2017. p. 315.

HILL, Steven. Raw deal: how the "Uber economy" and runaway capitalism are screwing American workers. 1st ed. New York: St. Martin’s Press, 2015.

LUXEMBURGO. Tribunal de Justiça da União Europeia (TJUE). Processo C-434/15. Autor: Asociación Profesional Elite Taxi. Réu: Uber Systems Spain. Juiz Rel. D. Šváby. DJe: 20/12/17.

MANNRICH, Nelson. Empregabilidade, ocupação e novas formas de trabalho. Revista da Faculdade de Direito da Universidade de São Paulo. São Paulo, v. 100, p. 103-119, jan./dez. 2005. (Disponível em <https://www.revistas.usp.br/rfdusp/article/download/67666/70274/>. Acesso em 31.out.18.)

MANNRICH, Nelson. Direito do trabalho em tempos de crise: qual a medida da reforma?. Revista eletrônica [do] Tribunal Regional do Trabalho da $9^{a}$ Região, Curitiba, PR, v. 6, n. 58, p. 31-47, mar./abr. 2017. Disponível em

<https://juslaboris.tst.jus.br/bitstream/handle/20.500.12178/105532/2017_m 
annrich_nelson_direito_trabalho.pdf?sequence=1\&isAllowed=y $>$. Acesso em 13.nov.19.

NASCIMENTO, Amauri Mascaro. Curso de Direito do Trabalho. $24^{\mathrm{a}}$ ed.. São Paulo, Saraiva, 2009. 1387 p.

MARTINS, Sergio Pinto. Direito do Trabalho. $24^{\mathrm{a}}$ ed.. São Paulo: Atlas, 2008. 128-203 p.

MUNIZ, Mariana. Justiça do Trabalho de SP nega vínculo de emprego entre motorista e Cabify. Jota, Brasília. Disponível em $<$ https://www.jota.info/tributos-e-empresas/trabalho/justica-trabalho-negavinculo-motorista-cabify-20072018>. Acesso em 19. Out. 2018.

PAULO, Vicente; ALEXANDRINO, Marcelo. Manual de direito do trabalho. $17^{\text {a }}$.ed. Rio de Janeiro: Forense; São Paulo: Método, 2013, p.1022.

PEREIRA, Caio Mário da Silva. Instituições de Direito Civil. 25ª ed. Rio de Janeiro: Forense, 2012. p. 179-186.

KRAMER, Josiane Caldas. A Economia Compartilhada e a Uberização do Trabalho: Utopias do Nosso Tempo? Dissertação - Universidade Federal do Paraná. Paraná, 2017. 129 p. Disponível em <https://acervodigital.ufpr.br/bitstream/handle/1884/47786/R\%20$\%$ 20D\%20-\%20JOSIANE\%20CALDAS\%20KRAMER.pdf?sequence=1 > Acesso em 23.out.18. 
REINO UNIDO. UK Employment Tribunal. Caso 2202551/2015. Autor: Mr. Y Aslam, Mr J Farrar e o. Réu: Uber B.V., Uber London, Uber Britannia. Juiz A. M. Snelson. DJe: 28/10/16.

ROMITA, Arion Sayão. Direito do Trabalho: Temas em Aberto. São Paulo: LTr, 1998. 474 - 477 p.

ROMITA, Arion Sayão. O Princípio da Proteção em Xeque e outros ensaios. São Paulo: LTr, 2003. 209-216 p. 